\begin{tabular}{|c|c|c|c|c|c|}
\hline MUNIBE Antropologia-Arkeologia & $n^{\circ} 70$ & $297-317$ & DONOSTIA & 2019 & ISSN 1132-2217 • elSSN 2172-4555 \\
\hline
\end{tabular}

\title{
Medieval rural landscapes and social change in Northern Spain: the archaeobotanical record for Zaballa (Alava, Basque Country)
}

\author{
Paisajes rurales medievales y cambio social en el norte de España: \\ el registro arqueobotánico de Zaballa (Álava, País Vasco)
}

KEY WORDS: Anthracology; Palynology; Deserted Village; Ancient Landscape; Middle Ages.

PALABRAS CLAVES: Antracología; Palinología; Población abandonada; Paisaje antiguo; Edad Media.

GAKO-HITZAK: Antrakologia; Palinologia; Herri abandonatua; Antzinako paisaia; Erdi Aroa.

Riccardo SANTERAMO ${ }^{(1) *}$, Begoña HERNÁNDEZ-BELOQUI(1) \& Juan Antonio QUIRÓS CASTILLO(1)

\begin{abstract}
In this paper, anthracological and palynological records of the Medieval deserted village of Zaballa in Alava (Basque Country, Northern Spain) are used to examine the transformation of rural landscapes. At this site, a large-scale archaeological project was carried out and a long period of occupation ( $6^{\text {th }}-16^{\text {th }}$ century) discovered. A good range of bioarchaeological and geoarchaeological evidence was also found. Archaeobotanical remains provided comprehensive proxies, which can be used to better understand the local economy, landscape dynamics, agrarian terraces and field systems. These data permit an examination of the role of the local community and the external agents that shaped agrarian and domestic spaces as well as the impact of aristocratic powers on rural settlements. The cross use of pollen and charcoal data allow us to relate the progressive reduction of the arboreal component during the Middle Ages with the increasing of the agrarian production, the periodical reorganization of the cultivated spaces, and the introduction of new production strategies.
\end{abstract}

\section{RESUMEN}

En este trabajo se emplean registros antracológicos y palinológicos de la aldea medieval abandonada de Zaballa en Álava (País Vasco, norte de España) para estudiar la transformación de los paisajes rurales. En este enclave se llevó a cabo un proyecto arqueológico a gran escala y se descubrió un largo periodo de ocupación (siglos VI-XVI). Además se encontró una gran variedad de evidencias bioarqueológicas y geoarqueológicas. Los restos arqueobotánicos aportaron indicadores integrales que pueden utilizarse para comprender mejor la economía local, la dinámica paisajística, las terrazas agrícolas y los sistemas para el campo. Estos datos permiten estudiar el papel de la comunidad local y los agentes externos que dieron forma a los espacios agrícolas y domésticos, así como el impacto de los poderes aristocráticos sobre los asentamientos rurales. El uso cruzado de datos procedentes del polen y el carbón nos permite relacionar la reducción progresiva del componente arbóreo durante la Edad Media con el aumento de la producción agraria, la reorganización periódica de los espacios de cultivo y la introducción de nuevas estrategias de producción.

\section{LABURPENA}

Lan honetan, erregistro antrakologikoak eta palinologikoak erabili ditugu, Erdi Aroko Zaballa herrixka abandonatukoak (Euskal Herria, Espainiaren iparraldea), landa-paisaiek izan duten eraldaketa aztertzeko. Gune horretan, eskala handiko proiektu arkeologiko bat egin zen eta okupazio-aldi luze bat aurkitu zen (VI-XVI. mendeak). Gainera, askotariko ebidentzia bioarkeologikoak eta geoarkeologikoak aurkitu ziren. Hondakin arkeobotanikoei esker, tokiko ekonomia, paisaiaren dinamika, nekazaritzako lurrak eta soroetarako sistemak hobeto ulertzeko erabil daitezkeen adierazle integralak eskuratu genituen. Datu horiek aukera ematen dute nekazaritzako eta etxe giroko espazioei forma eman zieten tokiko komunitatearen eta kanpoko eragileen rola aztertzeko; baita nekazaritza-kokaguneetan botere aristokratikoek izandako eragina aztertzeko ere. Polenetik eta ikatzetatik ateratako datuak gurutzatuta erabiltzeari esker, loturak egin ditugu, Erdi Aroan zuhaitz eremuak pixkanaka murriztearen eta nekazaritzako ekoizpena areagotzearen, landutako lurren aldizkako berrantolaketaren eta ekoizpen-estrategia berriak erabiltzen hastearen artean.

\footnotetext{
(1) Research Group in Heritage and Cultural Landscapes. Department of Geography, Prehistory and Archaeology. University of the Basque Country, UPV/EHU. C/Tomás y Valiente s/n, 01006 Vitoria-Gasteiz, Spain.

* Corresponding author (ORCID: 0000-0001-9844-4723). E-mail address: riccardo.santeramo@outlook.com
} 


\section{INTRODUCTION}

The archaeology of deserted villages has been acknowledged as an important subject in European medieval archaeology since the 1960s and 1970s (Chapelot and Fossier, 1980; Klápště and Jaubert, 2007). Initially research focused on depopulation processes and economic history, but later analyses of deserted villages led to a broader understanding of the transformation of settlement patterns, agrarian landscapes and rural societies in the longue durée (e.g. Klápště, 1995-2016; Dyer and Jones, 2010). The first studies were carried out mainly in northern Europe (Britain and Scandinavia), but since the 1980s archaeological analyses of deserted villages have also been undertaken in large areas of southern Europe (e.g. in France and Italy). The naissance du village, incastellamento and the formation of medieval landscapes and societies have all been examined (e.g. Zadora-Rio, 1995; Barceló and Toubert, 1998; Francovich and Hodges, 2003; Périn, 2004; Valenti, 2014).

Strictly speaking, no archaeological analysis of a deserted village in Iberia has been undertaken in recent years, although there have been some exceptions (Bazzana, 1978; Riu Riu, 1999). However, the main studies of rural settlement have examined matters such as the hydraulic systems in al-Andalus (Barceló, 1988), settlement patterns (Quirós Castillo, 2007) and castles and central places (e.g. Gutiérrez and Valor, 2014). The state of the art has changed over the last 30 years as a result of rescue archaeology (Demoule, 2012) and the realisation of specific archaeology projects (e.g. Valenti, 2004). The numerous preventive archaeological projects, frequently conducted on a very large scale in almost everywhere in Europe, have allowed for the analysis of rural settlements on a scale that would previously have been unfeasible. Recently, important syntheses and seminal works on several European regions and countries have been published (e.g. Hamerow, 2002; Peytremann, 2003; Francovich and Hodges, 2003; Rippon, 2008; Hamerow, 2012; Loveluck, 2013). Also in Spain, rescue archaeology has acted as an important stimulus for the study of medieval societies in the context of the archaeology of deserted villages (Quirós Castillo, 2009), especially in those areas surrounding big cities such as Madrid and Barcelona and during the construction of large-scale public works (e.g. Vigil-Escalera, 2005; Roig Buxó, 2011).

The landscape perspective became increasingly important in the 1970s and 1990s (Vernet, 1973; Aston, 1985) and, as a result, new approaches and techniques were developed to study medieval settlements. The study of prehistoric and Mediterranean archaeology involved the examination of palaeoenvironmental records and a greater understanding of these allowed us to analyse the roles of different socio-political agents and non-anthropic variables in the formation of medieval landscapes in southern Europe. Over the last three decades, a number of studies have been carried out in France (e.g. Durand, 1998; Galop, 1998; Davasse, 2000; Rendu, 2003; Durand and Leveau, 2004), Italy (e.g. Moreno, 1990; Di Pasquale et al., 2014; Mercuri et al., 2015) and Spain (e.g. Palet, 2002; Riera Mora, 2008; Orejas and Ruiz del Árbol, 2013; Narbarte-Hernández, 2019).

In the case of north-western Iberia, exciting progress in the study of medieval landscapes and deserted villages has recently been made as a consequence of large-scale preventive excavations and research projects focusing on rural communities, as well as the systematic analysis of palaeoenvironmental records and conceptual frameworks (Ballesteros Arias et al., 2006; Quirós Castillo, 2012; Fernández Mier et al., 2014; Sirignano et al., 2014).

In our territory, archaeobotanical studies have quite a long history, thanks to the pioneering work of Lydia Zapata and María José Iriarte Chiapusso (Iriarte-Chiapusso 1992; Iriarte-Chiapusso 1994; Iriarte-Chiapusso and Zapata 1996; Peña-Chocarro and Zapata 1996; Zapata 1999; Meaza and Zapata 1998, among others). Furthermore, new research projects have increased the available information regarding both the prehistoric and the historic regional palaeoenvironment (Peña-Chocarro et al., 2005; Iriarte-Chiapusso, 2009; Hernandez-Beloqui and Iriarte-Chiapusso, 2009; Sopelana and Zapata, 2009; Pérez-Díaz and López-Sáez, 2012; Sopelana, 2012; Corella et al. 2013; Hernandez-Beloqui et al., 2013; Hernández-Beloqui, 2015; Iriarte-Chiapusso et al. 2019, among others). However, there are fewer anthracological studies of historical contexts and they often focus on specific topics such as mountain foundries and ironworking (Gorrochategui et al., 1995; Zapata, 1997) or wood management and the landscape dynamics of mountain sites (Ruiz-Alonso, 2003). Only recently has more attention been paid to the formation of medieval settlements and rural landscape management (Ruiz-Alonso and Zapata, 2009; Ruiz-Alonso et al., 2009; Narbarte et al. 2018), although very few of these studies have been based on extensive excavations (Pérez-Díaz et al. 2015; Santeramo 2019) and we still lack general review works.

The aim of this paper is to discuss the archaeobotanical record for the deserted village of Zaballa (Alava, northern Iberia). The excavation of this site represents the most extensive preventive project carried out on a deserted medieval village in northern Iberia. Hence, Zaballa is a very suitable case for studying the diachronic transformation of the landscape, as well the role of rural communities and seigniorial agents in these transformations, the impact of rural activities on the local vegetation composition and woodland management practices.

\section{THE SITE: GEOGRAPHICAL AND HISTORICAL SETTING}

\subsection{Geographical setting and vegetation}

Zaballa (Iruña de Oca, Alava, x: 517.516; y: 4.738.616, UTM 30N, $604 \mathrm{~m}$ above sea (evel) is a deserted medieval village in the SW corner of the Alava Plain, $11 \mathrm{~km}$ SE of Vitoria-Gasteiz, the capital of Alava province and the Basque Country (northern Iberian Peninsula) (Fig. 1). From an environmental point of view, the Alava Plain is 


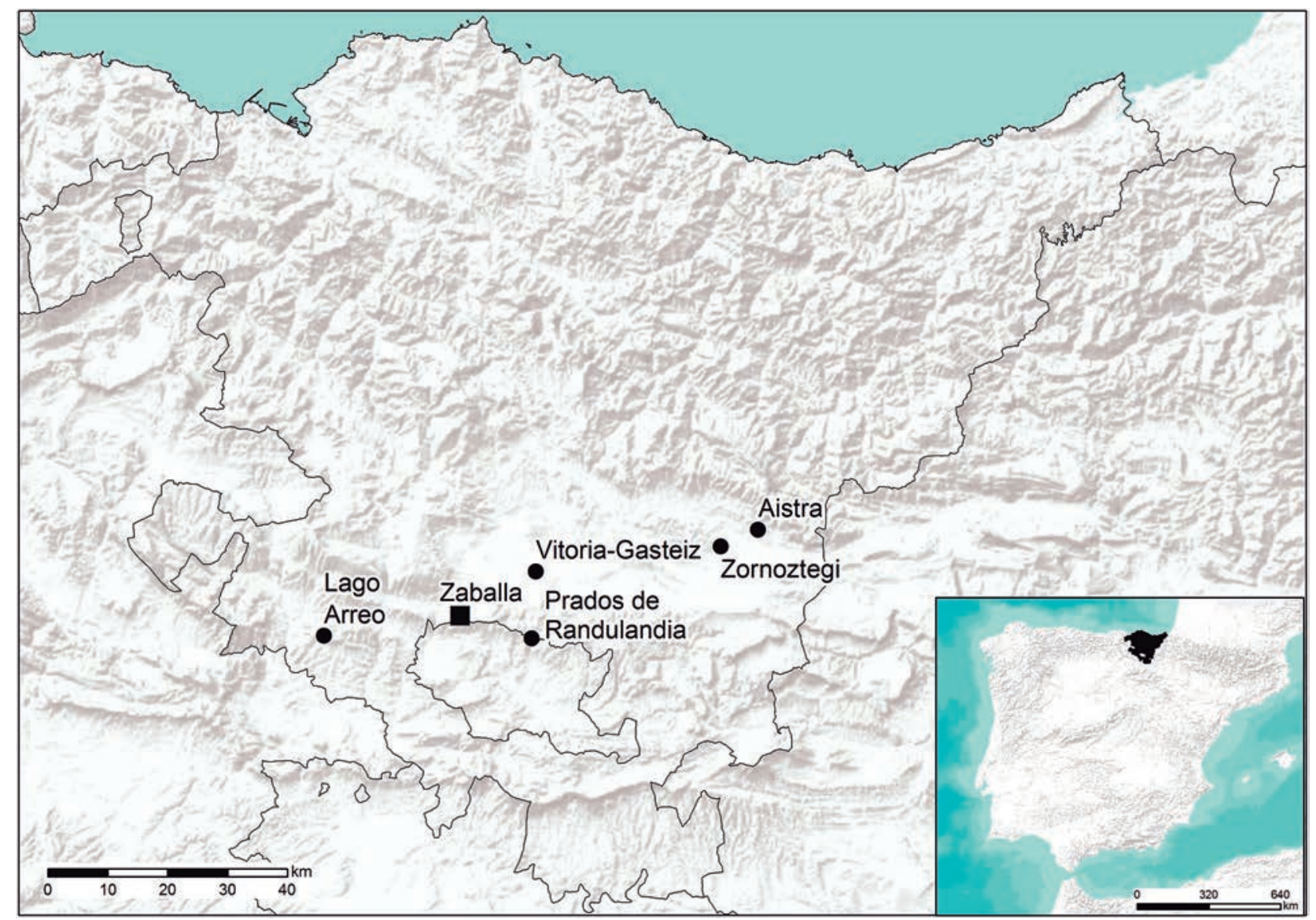

Fig. 1. Main sites cited in the text in the context of the Basque Country.

in the so-called 'Transition zone' and is characterised by its unique environment that results from a combination of oceanic and Mediterranean climatic conditions (Meaza, 1994; Loidi et al., 2011). The relief of the terrain is quite flat and there are large plains areas. The average annual temperature is $11-12^{\circ} \mathrm{C}$ and annual rainfall is around $700-900$ $\mathrm{mm}$. There are droughts in summer and in winter frost and snow are frequent and intense. The hydrographic network on the plain centres on the Zadorra River.

The area closest to the deserted village of Zaballa is now occupied by dryland farming crops, alternating with potatoes and beet. The presence of herbaceous plants that grow around Zaballa is possibly related to the abandonment of cultivated fields or to the human impact of fire or farming (Aseginolaza et al., 1989).

From a biological point of view, Zaballa is located in the Subatlantic valleys, although it is also very close to the Transition Mountains area (more specifically in the Vitoria Mountains zone - max. altitude 1176 m). Each area presents its own particularities. The gentle morphology and deep soil of the Alava Plain is very suitable for agriculture and livestock. In the southern part of the plain, beet, potato and cereal crops predominate. It is a highly anthropized landscape, where natural wood- lands only occupy those few spaces that are not suitable for other human activities. The most affected types of arboreal vegetation are the Quercus robur woodland and the riparian ash-alder woodland, which is mainly formed of Alnus glutinosa, Fraxinus angustifolia, Salix atrocinerea, etc. However, some deciduous woodlands survive in the area, especially oak forests in which $Q$. faginea predominates. Other species of this type may also be present (including Quercus robur), depending on the inclination of the slope and the soil moisture. Nowadays, most of the preserved local woodland vegetation is in the Vitoria Mountains area, immediately to the south of Zaballa, where few areas are suitable for agriculture and livestock and grazing have a low impact on the vegetation (Loidi et al., 2011; Aseginolaza et al., 1989). Here, thanks to the wet and shady conditions, there are beech forests above 800 m (Fig. 2), as well as deciduous oak forests of mainly Quercus faginea. Finally, we have to mention the presence of Quercus ilex and Quercus coccifera, both on the Alava Plain and in the Vitoria Mountains, in drier conditions with stony soils or in sunny areas on the edge of the deciduous forests. We should also note the high incidence of Pinus $\mathrm{sp}$ forestry plantations in mountainous areas (Loidi et al., 2011; Aseginolaza et al., 1989). 


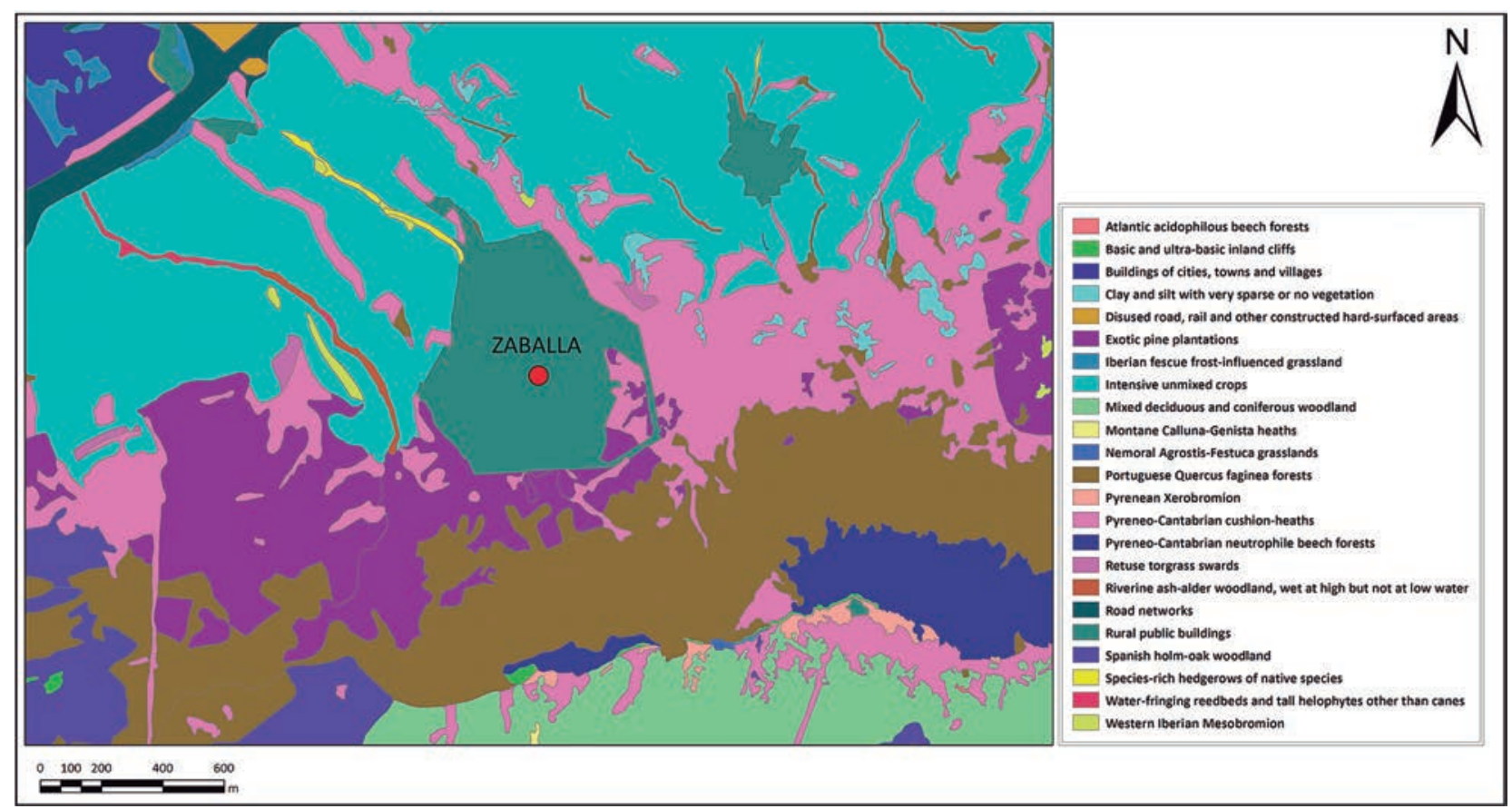

Fig. 2. Map of the local actual vegetation of Zaballa. From www.geoeuskadi.eus, modified with ARGIS 10.2 and using EUNIS habitat classification (following data in www.eea.europa.eu).

\subsection{The site of Zaballa}

The deserted village of Zaballa was excavated by the University of the Basque Country between February 2007 and November 2008 in view of the imminent construction of a new prison. The excavation of the open area involved all the domestic spaces, as well as the craft and agrarian spaces. Currently this is the most extensive preventive project to have been carried out on a deserted medieval village in northern Iberia. An area of more than 4 hectares was excavated and divided into two main sectors: the upper platform (Sectors 6000 and 7000), where the earliest evidence of occupation and the church were located, and the Zaballa Valley (Sectors 3000 and 4000), where the core of the early and late medieval village was located, including agrarian terraces and plots, irrigation systems and water channels (Fig. 3). Geoarchaeological studies of agrarian terraces and field systems were undertaken to holistically examine the medieval landscapes (Nicosia and Polo-Díaz, 2012; Ruiz del Árbol, 2012; Quirós Castillo et al., 2014).

Five main periods of occupation were identified in Zaballa (Quirós Castillo, 2012; 2013):

- Period 1. The first farms (c. 500-700). Between the $6^{\text {th }}$ and $7^{\text {th }}$ centuries AD, the site was characterised by low-intensity settlement: some farms consisted of a limited number of domestic units. The archaeological record for the period consists of some storage pits and post holes found on the upper platform.
- Period 2. The early medieval village (c. 700-950). A nucleation process and the formation of the peasant community occurred around AD 700, leading to the establishment of a village. The domestic occupation area covered more than $9000 \mathrm{~m}^{2}$.

- Period 3. The formation of a feudal society (c. 9501200). A church was built in the centre of the old village by external elite groups around AD 950. This church was probably linked to the local monastery attested in the $11^{\text {th }}$-century documentary record that belonged to the Tello Muñoz family ('the lords of Zaballa'). Social and political changes are also evidenced by the presence of manorial markers in the vicinity of the church, including large storage pits.

- Period 4. The late medieval manorial estate (c. 1200-1450). During the Late Middle Ages, there was a significant reduction in the size of the community. All the dwellings on the valley floor were completely removed when a massive agrarian space and a new canal system were built; the system irrigated the new productive spaces at the bottom of the valley. During this period, Zaballa can be defined as a genuine manorial estate characterised by the simplification of social complexity and the planned transformation of the entire site

- Period 5. The desertion (c. 1450-1610). At the beginning of the 15th century, the manor was donated by the owner, a member of the civil aristocracy, to the new monastery of Santa Catalina de Badaya, $5 \mathrm{~km}$ from Zaballa. The monastery collected rents 


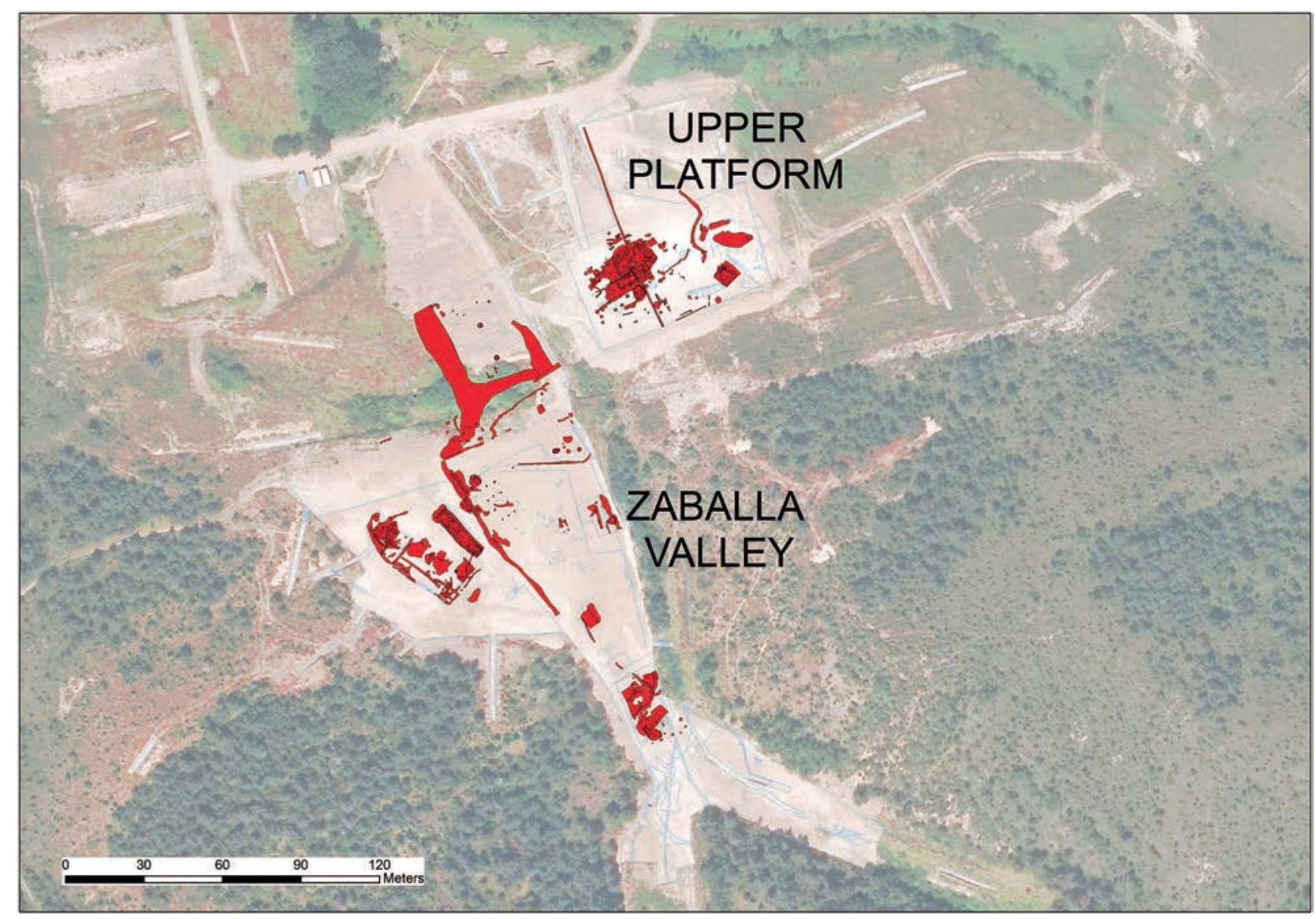

Fig. 3. General plan of Zaballa with the two main areas of excavation: Upper Platform (6000-7000) and the Valley (3000-4000).

and employed the peasants of other nearby villages when necessary. In the middle of the $15^{\text {th }}$ century, this vulnerability of the local peasant community was perhaps what determined the final abandonment of the village. Between the $15^{\text {th }}$ and the $17^{\text {th }}$ centuries, the area was mainly used for agricultural purposes and animal husbandry and the forested areas were exploited. The church was transformed into a dwelling, but after the middle of the $17^{\text {th }}$ century it was finally abandoned.

\section{MATERIALS AND METHODS}

Following a consolidated methodology (Pérez-Díaz 2009; López-Merino et al. 2010; Nelle et al., 2010, among many others), anthracological and palynological data were considered together with the aim of reconstructing both forest exploitation processes and vegetation dynamics. Thus, we were able to obtain a more complete knowledge of the medieval landscape.

Methodological details for pollen analysis were provided by Hernández-Beloqui (2012). Samples from different areas were collected in columns and processed using the standard palynological method (Burjachs et al., 2003). Although six columns were collected, only Column $\mathrm{F}$ obtained in the valley was described because it was the only one that provided information from the first period onwards. Furthermore, the use of CONISS cluster analysis (Grimm, 1987) significantly enhanced the zonation of the pollen diagram, allowing its chronological correspondence with Zaballa occupation sequence.

Altogether, 37 samples were collected every 7 cms; we avoided the top $43 \mathrm{~cm}$, since those could have been contaminated with modern pollen rain. The first 15 samples correspond to grey sediment (Context 3816) in which the archaeological structures corresponding to Period 3 settled. These are alluvial deposits resulting from water runoff. The next sediment in light brown (Context 3010) corresponds to the deposit from Period 4 and covers much of Area 3000, which points to the massive exploitation of the valley and the creation of agricultural parcels. This intermediate package corresponds to Samples 16-20. The remaining samples (2137) were recognised in a package corresponding to the dark brown earth mass (3001); this corresponded to the sedimentation of Periods 5-7 (dating from the second half of the $15^{\text {th }}$ century to the $21^{\text {st }}$ century). Charcoal collected from Sampling Point 16 (Context 3010) 
was dated to 1314 - 1443 cal AD, cal 2 sigma $95.4 \%$, (532 $\pm 37 \mathrm{BP})$.

The anthracological sampling of the available contexts at Zaballa followed the methodological principles of Chabal (1994), Chabal et al. (1999) and Figueiral and Mosbrugger (2000). Sediment samples were collected from 62 archaeological contexts from the five chronological phases, ranging from the $6^{\text {th }}$ to the $16^{\text {th }}$ centuries; 25 storage pit fills, 12 deposit fills, 7 hearths, 11 post hole fills, 3 building collapses, 1 trench fill, 1 pit fill and 2 indoor occupation surfaces were examined (Tables 1 and 2). Several synchronic contexts were studied in order to reduce interference from depositional disturbance and spatial casual/selective patterns of species distribution that may affect the charcoal assemblage. From each sample, 40 litres of archaeological deposit were processed, and each archaeological context was sub-sampled according to its dimensions and the

\begin{tabular}{|c|c|c|c|c|}
\hline \multicolumn{5}{|c|}{ GENERAL TABLE OF SAMPLES } \\
\hline Period & Time interval (yr) & Archaeological context & Sampled layers & Charcoal \\
\hline 1 & $500-700 \mathrm{AD}$ & $\begin{array}{l}\text { Deposit fill } \\
\text { Storage pit fill }\end{array}$ & $\begin{array}{l}6919 . \\
6342,6342 b, 6949 .\end{array}$ & $\begin{array}{l}100 \\
279\end{array}$ \\
\hline 2 & $700-950$ AD & $\begin{array}{l}\text { Deposit fill } \\
\text { Hearth } \\
\text { Building collapse } \\
\text { Post hole fill } \\
\text { Storage pit fill }\end{array}$ & $\begin{array}{l}6833,6912 . \\
6798,6815 . \\
6301 . \\
3551,6350,6355,6702,6719,6738,6786 . \\
3902,3904,3960,3960 \mathrm{~b}, 3992,6231,6233,6360,6511,6512,6561,6704, \\
6742,6768,6914 .\end{array}$ & $\begin{array}{l}29 \\
115 \\
119 \\
294 \\
694\end{array}$ \\
\hline 3 & $950-1200$ AD & $\begin{array}{l}\text { Deposit fill } \\
\text { Post hole fill } \\
\text { Storage pit fill } \\
\text { Trench fill }\end{array}$ & $\begin{array}{l}3354,3827,3832,6957 . \\
3838 . \\
3705,3997,4907,4912,6328,6530,6732 . \\
3539 .\end{array}$ & $\begin{array}{c}153 \\
5 \\
189 \\
36\end{array}$ \\
\hline 4 & $1200-1450 A D$ & $\begin{array}{l}\text { Deposit fill } \\
\text { Hearth } \\
\text { Building collapse } \\
\text { Indoor occupation surface } \\
\text { Pit fill } \\
\text { Post hole fill }\end{array}$ & $\begin{array}{l}4623,4624,6854 \\
4040,4232,4502 . \\
7517 . \\
4237 . \\
6330 . \\
6822,6884,7704\end{array}$ & $\begin{array}{c}41 \\
169 \\
62 \\
5 \\
29 \\
34\end{array}$ \\
\hline 5 & $1450-1610 A D$ & $\begin{array}{l}\text { Building collapse } \\
\text { Deposit fill } \\
\text { Hearth } \\
\text { Indoor occupation surface }\end{array}$ & $\begin{array}{l}4216 . \\
7575,7587 \\
3936,4223 \\
7563 .\end{array}$ & $\begin{array}{l}47 \\
56 \\
91 \\
22\end{array}$ \\
\hline & & & Tot. & 2569 \\
\hline
\end{tabular}

Tabla 1: Chronological sequence of the sampled Contexts. For each context, the type of the archaeological context and the number of studied charcoal are shown.

\begin{tabular}{|l|c|c|}
\hline \multicolumn{3}{|c|}{ GENERAL TABLE OF SAMPLES } \\
\hline \multicolumn{1}{|c|}{ Context type } & $\begin{array}{c}\text { Number } \\
\text { of contexts }\end{array}$ & $\begin{array}{c}\text { Number } \\
\text { of charcoals }\end{array}$ \\
\hline Storage pit fill & 25 & 1162 \\
Deposit fill & 12 & 379 \\
Hearth & 7 & 375 \\
Post hole fill & 11 & 333 \\
Building collapse & 3 & 228 \\
Trench fill & 1 & 36 \\
Pit fill & 1 & 29 \\
Indoor occupation surface & 2 & 27 \\
\hline \multicolumn{1}{|c|}{ Tot. } & $\mathbf{6 2}$ & $\mathbf{2 5 6 9}$ \\
\hline
\end{tabular}

Tabla 2: In this table, the number of the different types of archaeological context and the number of studied charcoals are shown. 
nature of the formative processes. The samples were processed using a flotation machine with a $0.5-\mathrm{mm}$ mesh in the flotation tank (Sopelana, 2012). Floating macroremains were recovered from $2 \mathrm{~mm}$ and $4 \mathrm{~mm}$ mesh sizes. Where possible, fragments over $4 \mathrm{~mm}$ were prioritised, owing to the evident statistical advantages in terms of taxa variety and charcoal assemblage representativeness (Chabal, 1997, p. 37). The taxonomic identifications were made with an incident light microscope working at 100x, 200x, 400x and 500x magnifications, using the reference wood collection of the Lydia Zapata Palaeobotanical Laboratory at the University of the Basque Country and wood anatomy atlases (Greguss, 1955; Schweingruber, 1990; Vernet et al., 2001).

As regards taxa nomenclature we use the anthracological nomenclature system provided by the University of Sheffield (Charles et al. 2009). The poor state of conservation (radial cracks, vitrification, deformation, etc.) of some charcoals made their identification difficult or even impossible. This resulted in 'undetermined' taxa.

The anatomical features of most of the deciduous Quercus samples were very close to features of Quercus faginea and, in some cases, those of Quercus robur and Quercus pyrenaica (vessel size; number and disposition of vessels in the early wood; pattern of vessels in late wood) (Vernet et al., 2001). However, Quercus $\mathrm{sp}$. has a high capacity for hybridisation in the chosen region (Aseginolaza et al., 1985, pp. 71-78; Aizpuru et al., 1999) and this makes identification at species level very difficult. For this reason, we preferred not to determine deciduous Quercus at species level. Anyway, the distinction between deciduous and evergreen species was possible. In addition, the identification of Rosaceae species was generally complicated owing to the presence of similarities in the anatomical features. Normally it is possible to distinguish between the subfamilies Rosaceae Maloideae and Rosaceae Prunoideae. However, in some cases we were able to identify the multivalent taxa $P$. armeniaca/dulcis/persica. In fact, we believe it is possible to determine this species when all the following features are clearly present in the sample: ring-porous arrangement of vessels, rays 7-10 cells in width, rays heterogeneous (Types 2 and 3), large size of early wood vessels (100-140 $\mu \mathrm{m}$ ) (Vernet et al., 2001, pp. 215-233; Schweingruber, 1990, p. 643). It should be noted that all the ambiguous samples were classified as Rosaceae Prunoideae.

\section{RESULTS}

\subsection{Pollen}

Pollen preservation in column F was good, despite the fact that some intervals were detected (Samples 3-5 and 17-18); in those samples the number of pollen grains was not statistically representative. Nevertheless, we managed to obtain information for Periods 1 to 5 , which will be described below (Fig. 4).

\subsubsection{Period 1. The first farms (Samples 1-2)}

Sparse woodland consisting of Pinus (8\%), Quercus roburtp. (0.8\%) and Taxus (3\%) was detected, with a notable contribution of Populus (5\%) and UImus (1\%). Juniperus is the main shrub, while the herbaceous stratum is dominated by Poaceae (20\%) and some anthropogenic indicators such as Compositae liguliflora (6\%), C. tubuliflora (4\%) and Plantago (3\%). There is a strong presence of humidity indicators (hygrophilous taxa and spores) that are constant throughout the sequence.

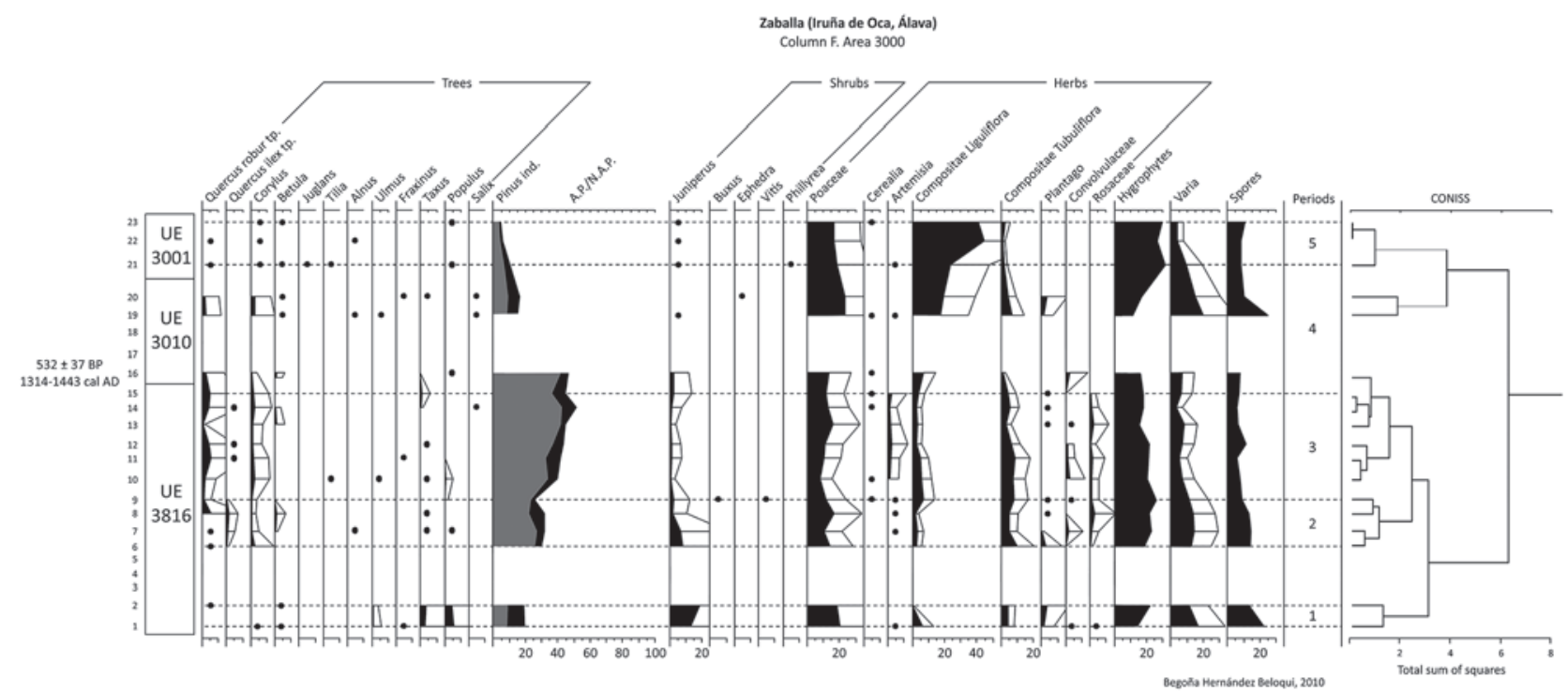

Fig. 4. Palynological diagram of column F from the Zaballa valley (redrawn from Hernández-Beloqui, 2012. 


\subsubsection{Period 2. The early medieval village (Samples 6-9)}

Pinus (20\%) becomes the main taxon in the arboreal pollen, followed by Corylus, Betula and evergreen Quercus. In contrast, riparian forest and, of particular note, Juniperus (2.5\% in Sample 9) reveal a marked decrease. Herbaceous taxa have similar values to those found in the previous period (58-62\%); however, the appearance of Vitis $(0.4 \%)$, Cerealia $(0.4 \%)$, Convolvulaceae $(2.1 \%)$ and Rosaceae $(0.4-3 \%)$ should be noted.

\subsubsection{Period 3. The formation of a feudal society (Samples 10-15)}

The Pinus curve increases (33\%), whereas other arboreal components remain at similar levels. Artemisia grows in the herbaceous stratum (2.5\% in Sample 12) and Cerealia continues to appear. Poaceae and anthropogenic indicators remain as in the previous periods, except for Plantago, which decreases (0.4\%).

\subsubsection{Period 4. The late medieval manorial estate (Samples 16 and 19-20)}

During this period, arboreal values fell dramatically (15\%, mainly Pinus), and all herbaceous components increased (mainly Poaceae and Compositae liguliflora) except for Artemisia, Plantago, Convolvulaceae and Rosaceae, which tended to disappear.

\subsubsection{Period 5. The abandonment (Samples 21-23)}

The trend from the previous period continued. In terms of arboreal pollen, Pinus remains $(4.6 \%$ in the last sample) and the presence of Juglans (0.4\%) should be noted. Other components almost disappear. Among herbaceous taxa, Compositae liguliflora dominates (41\%), followed by Poaceae (16\%) and hygrophilous taxa.

\subsection{Charcoal}

A total of 2569 charcoal fragments were analysed (2358 recovered from 4-mm mesh; 211 from the 2-mm mesh), and 30 taxa were identified. To increase our understanding, data were divided chronologically and grouped into the five main archaeological periods of the Zaballa sequence. For a general summary of the results see Tab. 3 .

\subsubsection{Period 1. The first farms (c. 500-700)}

In the first period, 379 charcoal samples from three storage pit fills (Contexts 6342, 6342b and 6949), and one deposit fill (Context 6919) were collected. The most important taxon is Fagus sylvatica $(59.4 \%)$ and deciduous Quercus (27.7\%), followed by Acer sp. (1.6\%), Fraxinus cf. F. angustifolia (0.8\%), and Rosaceae Maloideae $(0.5 \%)$ and Rosaceae Prunoideae (0.8\%). Low percentages of evergreen Quercus (0.3\%), Viburnum cf. V. lantana $(0.3 \%)$ and Arbutus sp. (0.3\%) were re- corded. Two fragments of Pinus mugo/nigra/sylvestris $(0.5 \%)$ are the only charcoal evidence for the presence of conifers in Zaballa before the $13^{\text {th }}$ century. It was not possible to determine the origin of some of the fragments (undetermined: $7.9 \%$ ).

\subsubsection{Period 2. The early medieval village (c. 700-950)}

For this period, 1251 charcoal samples from 15 storage pit fills (Contexts 3902, 3904, 3960, 3960b, 3992, 6231, 6233, 6360, 6511, 6512, 6561, 6704, 6742, 6768, 6914), two hearths (Contexts 6798, 6815), seven deposit fills (contexts 3551, 6350, 6355, 6702, 6719, 6738, 6786), two deposit fills (Contexts 6833, 6912) and one building collapse (Context 6301) were analysed.

Fagus sylvatica (45\%) decreased in comparison with the previous period, but it is still the most represented taxon. Deciduous Quercus is present (29.7\%), while Fraxinus cf. F. angustifolia (0.5\%) decreases and low percentages of Fraxinus excelsior (0.2\%) were found. Acer sp. (0.9\%) also decreases. Cornus sp. (0.2\%) and Corylus avellana (4.2\%) appear in this period. Evergreen Quercus (0.9\%) and other evergreen species exhibit some spread: Arbutus sp. (0.1\%), cf. Artemisia (0.1\%), Rhamnus/Phillyrea (0.5\%) and Viburnum cf. V. lantana $(0.2 \%)$. Rosaceae Maloideae (0.9\%) and Rosaceae Prunoideae $(0.6 \%)$ are also present. The presence of Juglans regia $(6.9 \%)$ and Vitis vinifera $(0.1 \%)$, should be noted. Betula sp. (0.1\%), Labiatae (0.2\%), Lonicera sp. $(0.1 \%)$, Monocotyledon $(0.1 \%)$ and cf. Viscum $(0.1 \%)$ are also present. It was not possible to determine the origin of some of the fragments (undetermined: $8.8 \%$ ).

\subsubsection{Period 3. The formation of a feudal society (c. 950-1200)}

383 fragments were sampled from seven storage pit fills (Contexts 3705, 3397, 4907, 4912, 6328, 6530 and 6732) and four deposit fills (Contexts 3354, 3827, 3832 and 6957), one trench fill (Context 3539) and one post hole fill (3838).

Data for this period indicate some changes occurring in the taxa composition. Fagus sylvatica (37.1\%) continues to be the dominant species but levels are lower than in the previous period. Deciduous Quercus $(29.2 \%)$ remains stable. Fraxinus cf. F. angustifolia $(1.8 \%)$ is at its highest level. Rosaceae Maloideae remain quite stable $(1 \%)$, while the increase in Rosaceae Prunoideae is interesting (6.8\%). From this family, Prunus armeniaca/dulcis/persica (2.6\%) stands out. Evergreen Quercus (3.4\%) reaches its maximum level and evergreen vegetation values increase with the presence of Arbutus sp. (0.5\%), cf. Daphne (0.3\%) and Rhamnus/Phillyrea (0.3\%). Vitis vinifera (1\%), Leguminsae $(0.3 \%)$ Acer sp. (0.8\%), Ulmus sp. (0.3\%) are also present. Due to the state of conservation of the charcoal samples (high vitrification and/or deformation), $14.6 \%$ of the fragments remained undetermined. 


\begin{tabular}{|c|c|c|c|c|c|c|c|c|c|c|c|}
\hline \multicolumn{12}{|c|}{ GENERAL TABLE OF SAMPLES } \\
\hline & \multirow{2}{*}{$\begin{array}{c}\text { Period } \\
\text { Absolute number / percentages }\end{array}$} & \multicolumn{2}{|c|}{$1(500-700)$} & \multicolumn{2}{|c|}{$2(700-950)$} & \multicolumn{2}{|c|}{$3(950-1200)$} & \multicolumn{2}{|c|}{$4(1200-1450)$} & \multicolumn{2}{|c|}{$5(1450-1610)$} \\
\hline & & $n^{\circ}$ & $\%$ & $n^{\circ}$ & $\%$ & $\mathbf{N}^{\circ}$ & $\%$ & $\mathbf{N}^{\circ}$ & $\%$ & $\mathbf{N}^{\circ}$ & $\%$ \\
\hline \multirow{31}{*}{ Taxa } & Acer sp. & 6 & $1,6 \%$ & 11 & $0,9 \%$ & 3 & $0,8 \%$ & 1 & $0,3 \%$ & 5 & $2,3 \%$ \\
\hline & Arbutus sp. & 1 & $0,3 \%$ & 1 & $0,1 \%$ & 2 & $0,5 \%$ & 1 & $0,3 \%$ & & \\
\hline & cf. Artemisia & & & 1 & $0,1 \%$ & & & & & & \\
\hline & Betula sp. & & & 1 & $0,1 \%$ & & & & & & \\
\hline & Cornus sp. & & & 3 & $0,2 \%$ & & & 1 & $0,3 \%$ & & \\
\hline & Corylus avellana & & & 52 & $4,2 \%$ & & & 1 & $0,3 \%$ & & \\
\hline & cf. Daphne & & & & & 1 & $0,3 \%$ & & & & \\
\hline & Erica sp. & & & & & & & 1 & $0,3 \%$ & & \\
\hline & Fagus sylvatica & 225 & $59,4 \%$ & 563 & $45,0 \%$ & 142 & $37,1 \%$ & 59 & $17,4 \%$ & 33 & $15,3 \%$ \\
\hline & Fraxinus cf. F. angustifolia & 3 & $0,8 \%$ & 6 & $0,5 \%$ & 7 & $1,8 \%$ & 2 & $0,6 \%$ & & \\
\hline & Fraxinus excelsior & & & 2 & $0,2 \%$ & & & & & & \\
\hline & Gymnosperm & & & & & & & 10 & $2,9 \%$ & & \\
\hline & Juglans regia & & & 86 & $6,9 \%$ & & & 54 & $15,9 \%$ & 56 & $25,9 \%$ \\
\hline & Juniperus sp. & & & & & & & 6 & $1,8 \%$ & 1 & $0,5 \%$ \\
\hline & Labiatae & & & 2 & $0,2 \%$ & & & & & & \\
\hline & Leguminosae & & & & & 1 & $0,3 \%$ & 2 & $0,6 \%$ & 8 & $3,7 \%$ \\
\hline & Lonicera sp. & & & 1 & $0,1 \%$ & & & & & & \\
\hline & Monocotyledon & & & 1 & $0,1 \%$ & & & & & & \\
\hline & Pinus mugo/nigra/sylvestris & 2 & $0,5 \%$ & & & & & & & & \\
\hline & Populus/Salix & & & & & & & & & 1 & $0,5 \%$ \\
\hline & Prunus armeniaca/dulcis/persica & & & & & 10 & $2,6 \%$ & & & & \\
\hline & Quercus (deciduous) & 105 & $27,7 \%$ & 371 & $29,7 \%$ & 112 & $29,2 \%$ & 92 & $27,1 \%$ & 50 & $23,1 \%$ \\
\hline & Quercus (evergreen) & 1 & $0,3 \%$ & 11 & $0,9 \%$ & 13 & $3,4 \%$ & 1 & $0,3 \%$ & 5 & $2,3 \%$ \\
\hline & Rhamnus/Phillyrea & & & 6 & $0,5 \%$ & 1 & $0,3 \%$ & & & & \\
\hline & Rosaceae Maloideae & 2 & $0,5 \%$ & 11 & $0,9 \%$ & 4 & $1,0 \%$ & 17 & $5,0 \%$ & 3 & $1,4 \%$ \\
\hline & Rosaceae Prunoideae & 3 & $0,8 \%$ & 7 & $0,6 \%$ & 26 & $6,8 \%$ & 25 & $7,4 \%$ & 2 & $0,9 \%$ \\
\hline & Ulmus sp. & & & & & 1 & $0,3 \%$ & & & & \\
\hline & Viburnum cf. V. lantana & 1 & $0,3 \%$ & 3 & $0,2 \%$ & & & & & & \\
\hline & cf. Viscum & & & 1 & $0,1 \%$ & & & & & & \\
\hline & Vitis vinifera & & & 1 & $0,1 \%$ & 4 & $1,0 \%$ & 34 & $10,0 \%$ & 16 & $7,4 \%$ \\
\hline & undeterminated & 30 & $7,9 \%$ & 110 & $8,8 \%$ & 56 & $14,6 \%$ & 33 & $9,7 \%$ & 36 & $16,7 \%$ \\
\hline \multicolumn{2}{|c|}{ Tot. / period } & 379 & & 1251 & & 383 & & 340 & & 216 & \\
\hline \multicolumn{2}{|l|}{ Tot. } & \multicolumn{10}{|c|}{2569} \\
\hline
\end{tabular}

Tabla 3: General table of studied charcoals. The absolute number and percentages of each taxon are expressed. Archaeological contexts studied are grouped into the five main chronological periods of the medieval history of Zaballa.

\subsubsection{Period 4. The late medieval manorial estate (c. 1200-1450)}

For this period, three hearths (Contexts 4040, 4232, 4502), three deposit fills (Contexts 4623, 4624, 6854), three post hole fills (Contexts 6822, 6884, 7704), one pit fill (Context 6330), one indoor occupation surface (Context 4237) and one building collapse (Context 7517) were sampled. In total, 340 charcoal samples were studied.

Fagus sylvatica (17.4\%) continues to decrease, while the presence of deciduous Quercus (27.1\%) re- mains quite stable and overtakes, for the first time, Fagus sylvatica. It should be highlighted that the percentage of Juglans regia (15.9\%) was high and Vitis vinifera (10\%) grew notably. Evergreen Quercus (0.3\%) and evergreen vegetation, with Erica sp. (0.3\%) and Arbutus sp. (0.3\%) were detected. Rosaceae levels rose slightly (12.4\%). Gymnosperm (2.9\%), Juniperus (1.8\%), Leguminosae (0.6\%) Acer sp. (0.3\%), Cornus sp. (0.3), Corylus avellana (0.3) and Fraxinus cf. F. angustifolia $(0.6 \%)$ are also represented. $9.7 \%$ of the fragments were undetermined. 


\subsubsection{Period 5. The abandonment (c. 1450-1610)}

For the last period two hearths (Contexts 3936, 4223), two deposit fills (Contexts 7575, 7587), one occupation surface (Context 7563) and one building collapse deposit (Context 4216) were sampled. A total of 216 charcoals were analysed.

Deciduous Quercus is again the most highly represented taxon (23.1\%), while Fagus sylvatica (15.3\%) fells to the lowest percentage of the Middle Ages. Vitis vinifera $(7.4 \%)$ is well represented, and Juglans regia $(25.9 \%)$ is at its highest. Riverine vegetation is attested for the first time by the appearance of Populus/Salix $(0.5 \%)$. Evergreen species are not recorded except for evergreen Quercus (2.3\%). Rosaceae Maloideae (1.4\%) and Rosaceae Prunoideae $(0.9 \%)$ are present, although the percentages are quite low. Leguminosae (3.7\%) Acer sp. (2.3\%), Juniperus (0.5\%) are also present. Due to the state of conservation of the charcoal samples (high vitrification and/or deformation), 16.7\% of the fragments remained undetermined.

\section{DISCUSSION}

The discussion is divided into two main sections. In the first part we will discuss the presence and trends of the main taxa identified through anthracological and palynological analyses. In the second part we use both records to reconstruct the diachronic landscape dynamic of the site. Hearths and building collapses were ex- cluded from this section in order to avoid biased data. As is common, some species were overrepresented in hearths and other structural layers, owing to the nature of their charcoal assemblages (Chabal, 1994).

\subsection{Main taxa}

\subsubsection{Fagus sylvatica}

Throughout the whole anthracological sequence the main arboreal components were Fagus sylvatica and mixed deciduous forest taxa (mainly deciduous Quercus). Fagus sylvatica is the dominant species in the Pyrenean-Cantabrian beech forest, which still grew a few kilometres south of Zaballa, in the Vitoria Mountains. This is quite a monospecific woodland as it is mostly made up of Fagus sylvatica and some Taxus baccata and Sorbus aria, as well as small quantities of shrubs. In the Basque Country this type of vegetation normally occupies the upper part of the limestone mountains. In the area of Zaballa, owing to its southerly position, this type of vegetation grows at above $800 \mathrm{~m}$ (Michel and Gil, 2013)

The palynological analysis of the peat from Prados de Randulanda (Pérez Díaz and López-Sáez, 2012; 2014), located $5 \mathrm{~km}$ above the site of Zaballa, provides evidence for the existence of beech trees during the Middle Ages. Thus, the presence of Fagus sylvatica in the anthracological data, along with its absence in the palynological data for the site throughout the whole se-

\section{Zaballa (Iruña de Oca, Álava)}

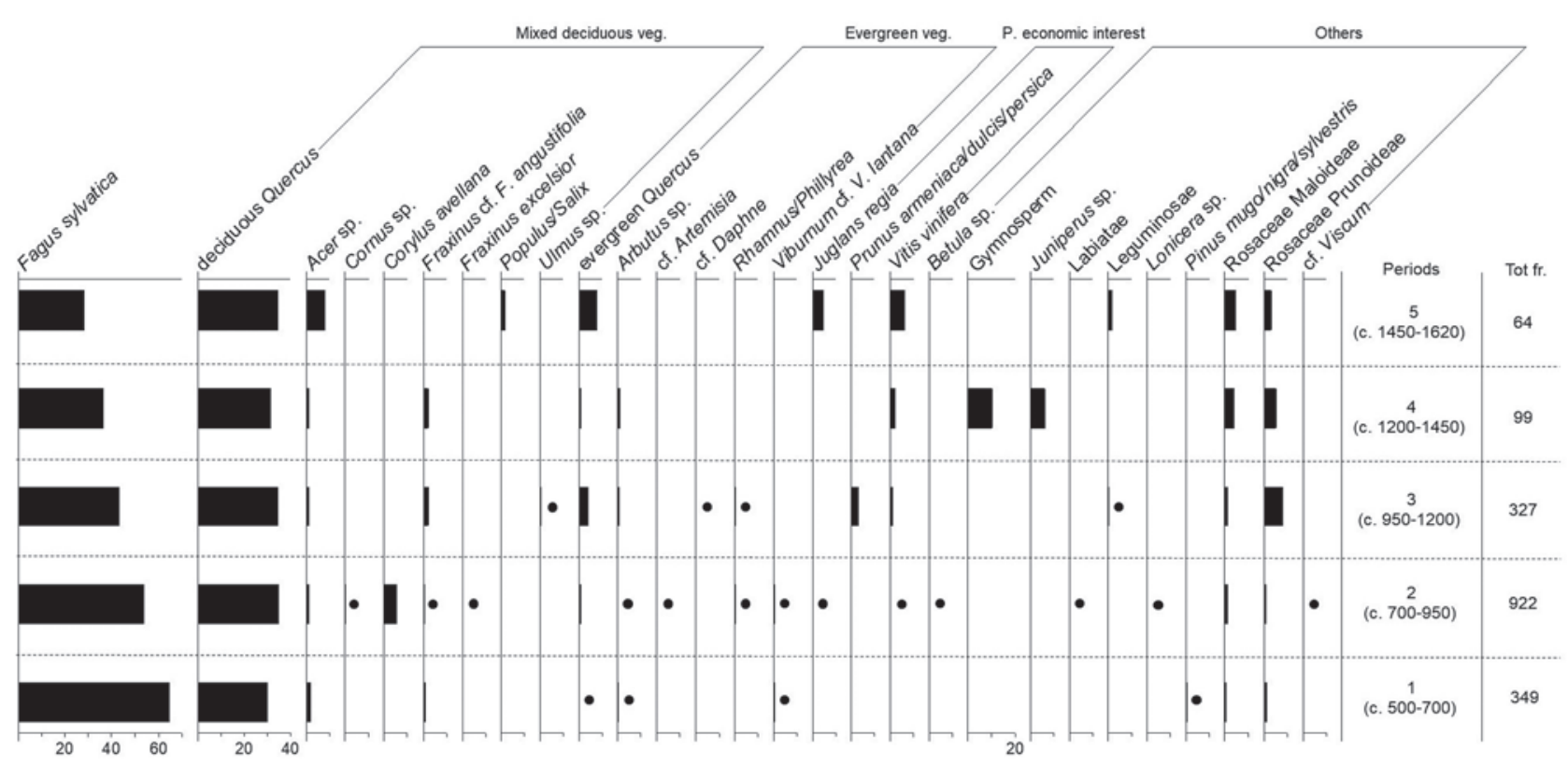

Santeramo Riccardo, 2019

Fig. 5. Diagram of landscape dynamics. Charcoal data (\%) shows main trends in the wood exploitation. Charcoals from building collapses and hearths are not taken into account. 
quence, suggests the existence of an exploited beech forest situated some distance from the settlement. The local inhabitants may have journeyed quite far from the village in search of this specific wood, perhaps because of its technical uses and calorific properties.

Beech forests were intensively exploited for wood and fuel throughout the Middle Ages. This exploitation decreased consistently from c. 700 onwards. In Prados de Randulanda, the pollen of beech species remains at stable levels until approximately $720 \pm 30$ BP (12461383 cal AD). A slight decline occurred after this time (Pérez Díaz and López-Sáez, 2012; 2014). In the medieval town of Gasteiz, this dynamic is reversed. Fagus sylvatica was an important source of fuel for domestic fires and a clear increase in its exploitation can be detected throughout the Middle Ages (Zapata and Ruiz-Alonso, 2013). This trend may suggest the existence of a wood trade between the medieval town of Vitoria and the ru$\mathrm{ral} /$ mountain sites of the region. In this context, the decline of this species in Zaballa may be the consequence of an increasing demand in the town.

In central and southern Europe, beech exploitation has frequently been linked to charcoal production and metallurgical activities (Ludemann, 2010; Nelle et al., 2010; Paradis-Grenouillet et al., 2015; Jean-Marc and Manon, 2013; Davasse, 2000; Dupin et al., 2017). Several regional studies (García-Antón et al., 1989; Gorrotxategi et al., 1999; Pérez Díaz et al., 2009) have linked the decline of broadleaved trees to the exploitation of wood by foundries, which played an important role in the economy of many mountain areas of the medieval Basque Country (Quirós Castillo, 2016). Although no smelting facilities have been found in Zaballa, the remains of small smithy structures intended for the forging or repair of domestic tools were most likely located in the valley. However, at sites such as the Oiola IV foundry (Trapagarán, Biscay), Fagus sylvatica and deciduous Quercus did not appear as the most exploited taxon and no forestry selection is detected (Zapata, 1997). In short, in terms of charcoal production and foundry activities, there are different anthracological patterns in the Basque Country. Thus, in Zaballa it is not possible to relate Fagus sylvatica fluctuations in these activities. Other drivers should be considered, namely the ecological competition between species favoured by human interference (Pott 1985).

\subsubsection{Mixed deciduous woodland}

The anthracological data reveal the presence in the local landscape of deciduous Quercus, Acer sp., Corylus avellana Fraxinus excelsior and shrubs belonging to the Rosaceae Maloideae and Rosaceae Prunoideae families. They are some of the most important species in the present-day mixed deciduous woodlands growing close to the area of the Zaballa site. Moreover, during the studied period, small quantities of Cornus sp., Fraxinus cf. F. angustifolia, Ulmus sp. and Populus/Salix are found. These species may have grown in damp soil inside the deciduous woodland, although they could also be evidence of riparian vegetation that may have spread near the Zadorra River and its tributaries.

However, in the area of Zaballa, deciduous Quercus is a very suitable species. Thus, considering both the potential spread of deciduous oak trees in the area and their constant use during the Middle Ages (Tab. 3), we believe that the mixed deciduous woodlands were the nearest available arboreal sources the inhabitants of Zaballa could have used and exploited for timber, fuel and pasture.

It is noteworthy that the isotopic analysis of early medieval pig remains from Zaballa suggests that these animals were pastured in woodland (Sirignano et al., 2014). Indeed, during the Middle Ages (and earlier), fruit, branches and leaves from species such as Quercus sp., Fraxinus sp., Acer sp., Populus sp. and Corylus avellana were used as fodder for cattle (Euba Rementeria, 2005). The mixed deciduous woodland is particularly suitable for wood-pasture land management. In this particular case, arboreal vegetation was left more open to allow for animal pasture. The vegetation of this type of forest was not only used as cattle fodder but also as an important source of firewood (Rackham, 1982; Moreno, 1990). The regeneration of the woody plants was guaranteed by a specific practice called pollarding; wood was cut from trees at a height of 2-4 $\mathrm{m}$ so that the new shoots were not eaten by the cattle.

Contrary to what happened to the beech forest, the exploitation of mixed deciduous woodland remained stable during the Middle Ages. Different kinds of wood management could have been applied to these types of vegetation. The economic importance of mixed deciduous woodland may have prevented over-exploitation, while beech forest may have been specifically exploited for timber and firewood.

\subsubsection{Taxus sp. and Pinus sp.}

It is possible to notice that some species are present in our palynological data, while absent in the anthracological ones. Low percentages of Taxus sp. are recorded for the first period, but no charcoal was found. Presumably, Zaballa inhabitants did not use this kind of wood species simply because of its low presence in the environment. Anyway, other considerations should be made. Taxus baccata is a typical species of the local beech forest and it is traditionally not exploited for carpentry or as a fuel, but as an ornamental tree (Aseginolaza et al. 1989; Aizpuru et al. 1999). Its absence in the anthracological data could also be explained as a cultural bias.

However, understanding the strong discrepancy between records in the case of Pinus sp. has greater relevance. It is difficult to discern through pollen analysis which species of Pinus sp. were used in Zaballa, as the identification remains at genus level. In any case, 
we have to consider that only Pinus sylvestris and Pinus halepensis grow naturally in this part of the Alava Plain (although the latter is more adapted to southern zones of Alava province) (Aseginolaza et al. 1989, p. 274; Aizpuru et al., 2010; Loidi et al., 2011). Nowadays, other species grow near Zaballa, including Pinus nigra, P. radiata, P. pinaster, although their presence is mostly the result of modern arboreal cultivation (Aseginolaza et al. 1989, p. 67).

Charcoal analysis has recorded the presence of $\mathrm{Pi}$ nus mugo/nigra/sylvestris. However, we presume that in the Zaballa area during the Middle Ages the most suitable species among the above mentioned three was Pinus sylvestris for the reasons already explained.

An important discrepancy in the representation of Pinus sp. was detected between anthracological data (where it has a low presence) and palynological data (where it constitutes the main arboreal component). This is not unusual in the Basque Country. Other sites, such as the Bronze Age site of Peña Parda (Alava) (Ruiz-Alonso et al., 2011) and the Medieval site of Arrubi (Gipuzkoa) (Ruiz-Alonso, 2003; Iriarte-Chiapusso, 2003) record similar trends. This 'anomaly' is caused by the overrepresentation of pine in pollen assemblages, due to its ability to travel long distances. Several authors have already reported that incoming Pinus sp. pollen may dominate the pollen spectra at sites where this taxon is absent (Court-Picon et al., 2006, p. 161). Nevertheless, the constant presence of pine pollen in the palaeoenvironmental records of the region (e.g. Mazier et al., 2006, p. 98) combined with the fact that Pinus sylvestris and Pinus halepensis could have grown naturally in the region cannot be ignored. Thus, taking into account all the previous considerations, we think that two options are likely:

1. Pinus sp. may be present on a regional scale but absent in the most local vegetation.

2. Despite the presence of pine trees in the vicinity of the site, a cultural preference may have led to low exploitation of Pinus sp.

We believe the second option should be considered as the most likely, as traditionally pine wood is considered unsuitable for combustion-related domestic activities (Aseginolaza et al. 1989). At the same time, we exclude that Pinus sp. could have been the main arboreal taxon. In that case, we believe pine wood should have been used at least for some activities, as in other medieval sites (Ntinou et al., 2013).

\subsubsection{Rosaceae}

The Rosaceae family includes trees, shrubs and herbs. The presence of Rosaceae in the charcoal assemblage could be the result of pruning trees and shrubs that may have been naturally present near Zaballa in the local oak woodlands, riparian vegetation or more open areas. Some of these plants could also have been favoured or even cultivated for the production of fruits.
Palynological analysis alone does not allow us to discern the species in the Roasaceae family, while anthracological analysis distinguishes between the subfamilies of Rosaceae Maloideae and Rosaceae Prunoideae. In some cases, more accurate identification is possible, and we have been able to identify some charcoal samples of $P$. armeniaca/dulcis/persica, an interesting multi-taxa that all refer to edible species. The absence of Rosaceae fruit in the Zaballa contexts may be due to taphonomic reasons. In our territory, carpological remains are generally preserved only after their partial combustion (Teira-Brión, 2013) and this would not have occurred with fruits that were consumed raw, as in the case of Prunus sp.

In any case, although it is currently only supposition, we believe that the finds of $P$. armeniaca/dulcis/persica charcoals (although only a few) could be considered as the possible remains of a cultivated fruit tree. In fact:

1.P. armeniaca, $P$. dulcis and $P$. persica, are not native to the region (Aseginolaza et al. 1989; Loidi et al., 2011).

2. The agrarian terraces were built during the same period as those species were developing.

3. Geoarchaeological analysis has concluded that 'the terraces were possibly used for vineyards, fruit orchards or the production of fodder for animals, rather than for crops requiring repeated tillage (e.g. cereals) and the periodic extirpation of weeds' (Nicosia and Polo-Díaz, 2012, p. 547).

\subsubsection{Juglans regia}

Juglans regia appears in the palynological data and is strongly represented in the anthracological records (up to $25.9 \%$ in Period 5). Currently, this species grows on the Alava Plain (Aizpuru et al., 2010) but it is not native to the region (Aseginolaza et al. 1989; Loidi et al., 2011).

Palynological analyses carried out by Beug (1975) led him to link the appearance of Juglans regia in Europe with the Roman expansion (around 2200 BP). This hypothesis has been questioned (Iriarte-Chiapusso, 1997, 674) and the presence of Juglans regia in previous chronologies has been noted (Carrión-García and Sánchez-Gómez, 1992; Sánchez-Goñi, 1988; Uzquiano, 1992). Its recovery in both the anthracological and palynological records is not necessarily proof of its cultivation. However, in other areas, it was interpreted as a clear anthropic marker (Alcolea-Gracia et al., 2016). In our territory, Juglans regia charcoal is usually recorded in low percentages, as is the case of the medieval village of Gasteiz (Zapata and Ruiz-Alonso, 2013). In Zaballa, the abundant representation of Juglans regia within the charcoal assemblage, especially that related to building collapse archaeological contexts, may suggest that the walnut tree was favoured 
and exploited for carpentry and not only for fuel or food. This high-quality wood is still used for cabinet-making today (Vignote-Peña et al., 2000) and several authors classify it as suitable for luxury items and furniture (Ginés-López, 1982, among others). The particular spatial distribution of Juglans regia in Zaballa, and its concentration on the upper platform appears to be related to high-status domestic contexts. Apart from during Period 5, Juglans regia appears in those areas where signs of social differentiation have been detected. The discovery of Juglans regia in the valley area during Period 5 does not contrast with the main trend. Juglans regia charcoal in the valley came from the collapse of domestic buildings. The last inhabitants of the village may have re-used materials and tools abandoned on the upper platform, which was once inhabited.

\subsubsection{Vitis vinifera}

Wild grape has grown on the Iberian Peninsula since the Middle Pleistocene and there is evidence that it has been cultivated since the Iron Age (Buxó and Piqué, 2008; Iriarte-Chiapusso et al., 2016). Several factors support the theory of Vitis vinifera cultivation during the Middle Ages on the Alava Plain. In particular, economic (due to its high profitability) and cultural factors (wine was necessary for liturgical use) should be noted. Vitis vinifera charcoal samples found in archaeological contexts are related to wood use and also to its maintenance. Periodic pruning generates small pieces of wood which would have been particularly useful for small domestic fires (Ruiz-Alonso et al., 2009).

Medieval archaeological records from northern Iberia demonstrate the importance of vineyards (Ruiz-Alonso et al., 2009; Zapata and Ruiz Alonso, 2013; Hernández-Beloqui, 2015). Moreover, this type of crop also appears in the written documentation of medieval Alava (Ruiz de Loizaga, 1988; García Fernández, 2012).

In Zaballa charcoal, pollen and seed remains (Sopelana, 2012), as well as pruning tools (Mansilla, 2012), testify to the cultivation of Vitis vinifera from the $8^{\text {th }}$ century onwards. In addition, in documents relating to the abandonment of the site, it is reported that the vineyards of Zaballa were uprooted and replaced by other crops between 1520 and 1530 (Díaz de Durana, 2012). Taking into account the spatial concentration of Vitis vinifera charcoal samples in the valley contexts, it is likely that vineyards were cultivated on the $10^{\text {th }}$-century agrarian terraces, perhaps interspersed with other fruit trees (Quirós Castillo et al., 2014). This is not surprising, as grapes require a particular type of soil and hydrological conditions, as well as skilled labour.

\subsection{Landscape dynamics}

Due to different variables, such as the presence of plant species, human selection, charcoal preserva- tion and sampling strategies, taxa percentages do not exactly prove the quantitative frequencies of each species in the landscape. However, using a combination of archaeological, anthracological and palynological data, we are able to put forward some hypotheses on palaeovegetation dynamics.

To better understand the ancient landscape dynamics, charcoal samples from fills (deposit, pit, post hole, storage pit and trench fills) and indoor occupation surfaces were studied. They are fairly representative of the palaeo-landscape since they originated from the various domestic/productive activities undertaken in Zaballa. Evidence from hearths and building collapses helps to enhance our knowledge of past vegetation, but this type of evidence is related to specific structure or short-term deposition (Chabal, 1994). In contrast, the study of occupation surfaces could give more precise results in terms of palaeo-environment reconstruction (Chabal, 1994). In Periods 1, 2 and 3, in contrast with others, no indoor occupation surface was analysed. For these reasons, the variety of species may be biased because of the different nature of the sampled contexts.

In Figure 5 we illustrate the percentages of taxa found within charcoal samples, calculated on the total number of analysed charcoals for each phase of the stratigraphic sequence. Charcoals from building collapses and hearths are not taken into account. Some taxa were grouped together in order to gain a better understanding of the dynamics of key local species and landscape dynamics. Five main groups were established:

1. Fagus sylvatica: we consider this taxon independently because it tends to form monospecific woodland in the mountain areas and because of its incidence in the data.

2. Mixed deciduous woodland: it represents the main arboreal species of the local oak forests and of the local riparian vegetation. They possibly represent the main and closest arboreal vegetation in the Zaballa landscape. Oak forest and riparian vegetation species are represented together, since in our territory the last ones could grow both near rivers ad in the wettest soils within the local oak forests (deciduous Quercus, Acersp., Cornus sp., Corylus avellana, Fraxinus cf. F. angustifolia, Fraxinus excelsior, Populus/Salix, Ulmus sp.).

3. Evergreen vegetation: it includes trees and shrub species better adapted to Mediterranean conditions. In our area, they could develop as a consequence of human activities (evergreen Quercus, Arbutus sp., cf. Artemisia, cf. Daphne, Erica sp., Rhamnus/Phillyrea, Viburnum cf. V. lantana).

4. Plants of economic importance: it includes plants with an economic and alimentary importance (since they are edible species) and which could be favoured or even cultivated (Prunus armeniaca/dulcis/ persica, Vitis vinifera, Juglans regia); 
5. Other taxa, such as species with sporadic and low representation in our anthracological data or with a wide range of spread on the territory and therefore not attributable to a specific group (Betula sp., Juniperus sp., Leguminosae, Lonicera sp., Monocotyledon, Pinus mugo/nigra/sylvestris, Rosaceae Maloideae, Rosaceae Prunoideae, cf. Viscum).

The discussion will be divided according to the different periods.

\subsubsection{The first farms (c. 500-700)}

The palaeovegetation from the first period provides evidence of a low-intensity anthropised landscape and a deforested area in the surroundings of Zaballa. The palynological record shows low arboreal pollen percentages and a strong presence of Plantago. Anthracological analysis provides additional information on the local arboreal vegetation. Forests of Fagus sylvatica (64.5\%) were probably situated in the upper parts of the valley, where atmospheric humidity is high and soil conditions are good for this species. Local inhabitants may have gone quite far up into the Vitoria Mountains in search of this specific type of wood, which was perhaps selected for its technical and calorific properties. High percentages of Fagus sylvatica may not indicate the precise extension of the beech woods in the immediate local landscape where this species was absent (Fig. 4). However, it seems that during the Dark Ages and the Early Middle Ages Fagus sylvatica was the wood most exploited for domestic activities. Closer to the settlement, the mixed deciduous woodland, in which deciduous Quercus (30.1\%) predominates, was possibly a widely spread tree vegetation. It may have grown near the village, while the riverine species may have spread lower, near the Zadorra River.

Evergreen vegetation species (evergreen Quercus $0.3 \%$; Viburnum cf. V. lantana 0.3\%; Arbutus sp. $0.3 \%$ ) could have grown inside or along the borders of the mixed deciduous woodland (Loidi et al., 2011, pp. 118-123; Costa-Casais et al., 2012, pp. 65-66), but their presence may also be related to human activity (e.g. for burning, timber and grazing). It is probable that open spaces formed by clearing woodland were created for farming or livestock purposes.

Carpological remains prove that cereals were consumed during this period, mainly Panicum/Setaria and Triticum and some Hordeum (Sopelana, 2012). Although no cereal pollen has been found, this could be due to the poor spatial diffusion ability of this kind of pollen, which is generally found just inside or close to the crop itself (Robinson and Hubbard, 1977; Hernández-Beloqui, 2015).

Additionally, zooarchaeological studies have attested the importance of meat in the local diet (Bos taurus, Sus domesticus, Ovis/Capra) (Grau-Sologestoa, 2015). The decentralisation of agrarian production and a reduction in long-distance trade may have led the local rural society to develop diversified production and subsistence strategies, which would have served to avoid the risks associated with specialisation. This pattern has been documented at other Alava sites and in early medieval settlements in central Iberia (Vigil-Escalera et al., 2014).

\subsubsection{The early medieval village (c. 700-950)}

During the second period, nucleation caused changes in local landscape, expanding crop areas and changing forest exploitation patterns. In general, the diversity of wood being exploited increased. Fagus sylvatica decreased notably (from $64.5 \%$ to $53.6 \%$ ), but continued to be the main arboreal taxon. Deciduous Quercus (34.6\%) and other mixed deciduous woodland species increased a little. The small increase in both evergreen vegetation and Rosaceae is not enough to be interpreted as the marker of an increase in local human impact. Nevertheless, arboreal pollen percentages decreased and species with an economic value appeared both in pollen (Cerealia, Vitis) and charcoal remains (Juglans regia, Vitis vinifera), testifying to the introduction or/and existence of a particular kind of tree cropping or woodland-management strategy. Although Vitis vinifera charcoal percentages notably increase from the $13^{\text {th }}$ century onwards, archaeological evidence (e.g. iron tools) confirms that it was cultivated during this period. The presence of Vitis vinifera in the charcoal assemblage is related to the pruning required for the maintenance of vineyards.

In any case, all the evidence paints a picture of a peasant society that was well connected to other villages and central places; its economy was based on production diversification and risk and specialisation were avoided (Halstead and O'Shea, 1989). Agriculture and local animal husbandry meant that communal pastures in the Vitoria Mountains were exploited and the combination of winter and spring cereals with other crops formed the basis of the Zaballa agrarian society (Sopelana, 2012; Grau-Sologestoa, 2015). The decrease in Fagus sylvatica and the appearance of new species (Cornus sp., Corylus avellana, Fraxinus excelsior, Betula sp., Lonicera sp., among others) may be related to a less selective wood catchment strategy. The exploitation of edible species (Juglans regia and Vitis vinifera) for wood should also be noted in this context, as cropping for food production and exploitation for wood was also practised. The development of the grapevine, which requires the capacity to invest in the seasonal participation of a large number of workers (Horden and Purcell, 2000) is a clear sign of community activities being undertaken in the village. Finally, another feature of the internal structure of peasant societies is the development of artisanal activities, which are evidenced by the production residues we have found in Zaballa.

In summary, from the $8^{\text {th }}$ century onwards, an important transformation took place in Zaballa. This process, which is documented in other regional palaeoenviron- 
mental records, such as those of Prados de Randulanda and Arreo Lake (Pérez Díaz et al., 2012, 2014; Corella et al., 2013), can be linked to the general expansion of peasant communities. These communities did not seem to be highly diversified from a social point of view, but they were very active in terms of transforming rural landscapes.

\subsubsection{The formation of a feudal society (c. 950-1200)}

In the third, period, a profound transformation occurred in the organisation of both the village and the surrounding landscape (Quirós Castillo, 2012, pp. 597 604). The most evident signs are the construction of a church in the heart of the medieval village, the displacement of the village, the total transformation of the village lands-cape by the construction of series of agrarian terraces and the diversion of the water courses to the valley bottom (Quirós Castillo et al., 2014).

In general terms, the anthracological data for this period exhibit few though important changes. Fagus sylvatica exploitation continues to decrease (43.4\%), while deciduous Quercus (34.3\%) and mixed deciduous woodland remain almost stable. The expansion of Rosaceae $(9.2 \%)$ and evergreen vegetation $(5.3 \%)$ is perhaps the sign of a new type of landscape management. The development of evergreen species may, however, reflect different events. It is possible that a less selective wood selection strategy involved an increasing quantity of these species. This change would have become necessary if new kinds of activities had been introduced in Zaballa. It is also possible that the expansion of the village and the reorganisation of the agricultural spaces may have led to deforestation and the spread of shrubs and evergreen vegetation. Finally, it must be said that more than one of the previous hypotheses could also be possible.

In the context of reorganisation, the finding of Prunus armeniaca/dulcis/persica (3.1\%) and Vitis vinifera (1.2\%) becomes even more interesting. Taking into account their spatial distribution within the village, close to the terraces in the valley, we may suggest that they were related to the increase in new economic and productive choices. Thus, the intensive cultivation of fruit trees on terraces and/or vineyards must be viewed as a profound change for the local economy and the landscape.

Pollen data also record those sociopolitical transformations and indicate the presence of more open vegetation; the mixed deciduous woodland may have been moved some distance from the village.

Summing up, the site was completely reorganised due the construction of a church related to a private monastery. This church had an evident political and economic role as it had several pits for the storage of rents. The farming activity of this period exhibits a certain degree of continuity; the diversification of agrarian production, the integration of crop and livestock activities, and the cultivation of long- and short-cycle crops, as well as fodder, should all be noted. However, a new distribution pattern of production activities is also detected, Rosaceae and evergreen vegetation spread and the terraces were concentrated in the Zaballa Valley. In other words, the dominion exercised by the Zaballa monastery meant that there was an effective system of rent collection. In addition to this, the innovations in agrarian production could explain the reorganisation of agrarian plots and the construction of terraces.

\subsubsection{The late medieval manorial estate (c. 1200-1450)}

In the fourth period, wood exploitation went on involving the surrounding woodland and the use of the deciduous Quercus (31.3\%) remains almost stable. Beech forests were still important in the local landscape, but they continue to decrease (from $43.4 \%$ to $36.4 \%$ ). On the contrary, there is an increase in the exploitation of Vitis vinifera (2\%). The use of other species, especially Gymnosperms (16.2\% with Juniperus sp.) and Rosaceae $(9.1 \%)$, could be related both to a change in the fuel wood exploitation and in the landscape management.

Pollen analysis records for this period emphasise the mass deforestation of the area. New open spaces were probably needed for extensive cereal growing and intensive fruit tree cultivation. Indeed, animal remains indicate a significant increase in bovines, which may be associated with an increase in agrarian production. In the area of the church, barley is almost the only species found. This is the first time in Zaballa farming production that evidence of economic specialisation can be noted. In the domestic area, diversification strategies were again attested.

The number of domestic units decreased in relation to the previous period, but the late medieval occupation can be defined in terms of a manorial estate. Historical documentation reports that the village came under the rule of a new seigneurial power and the valley was reshaped with raised fields. The reorganisation of the domestic area, the construction of a massive agrarian fill and a canal system are the most visible signs of targeted and planned social investment. The village takes the form of a settlement with specialised productive purposes and was probably involved in a complex economic system that included a network of settlements.

\subsubsection{The abandonment (1450-1610 ca)}

Trends observed in previous phases become particularly evident during the fifth period. Beech forest fell to the lowest percentage of the studied period, (28.1\%) while mixed deciduous woodland rises a bit, thanks to the presence of Acer sp. (7.8\%). The exploitation of evergreen vegetation and plants of economic interest rise: evergreen Quercus (7.8\%), Vitis vinifera (6.3\%) and Juglans regia $(4.7 \%)$ seem to be quite important species for the domestic activities of this period. These important changes may reflect a more open landscape, where the domestic occupation of the village disappeared but the economic exploitation of the territory continued. It is not a coincidence 
that in the palynological data for this period the lowest percentage of arboreal species can be noticed.

Historical documentation and archaeological sources have helped us understand this final stage. At the beginning of the $15^{\text {th }}$ century, the new monastery of Santa Catalina de Badaya Zaballa was donated by the local aristocracy. This monastery was not interested in preventing the demographic decline of the village or in addressing farming production in specialised terms, but only in collecting as much rent as possible. The employment of external farmers is a clear sign of this strategy. This explains the vulnerability of the local peasant community and perhaps also determined the final abandonment of the village in the $15^{\text {th }}$ century. From AD 1450 on, the site lacks any domestic archaeological evidence and only the church of Saint Tirso remains in place. The settlement of the 'last' Zaballa was probably specifically devoted to the agricultural and pastoral exploitation of the territory, where different kinds of crops took the place of arboreal vegetation.

\section{CONCLUSIONS}

The Zaballa archaeological study has attempted to describe the landscape transformations that occurred between the early and late Middle Ages, linking them to social changes.

Local woodland was a great resource for the rural community and was used for pasture and timber. Wood gathering and timber felling meant that beech forests and mixed deciduous woodlands were preferred. Nevertheless, over time, any species available locally was used as firewood. Furthermore, pollen and charcoal data indicate the progressive reduction of mixed deciduous woodland and the retreat of the beech forest in mountain areas.

The discussed transformations in vegetation cover and woodland management at Zaballa present parallelisms with other cases in north-western Iberia, as well as some interesting particularities. The main trends detected were as follows:

1. The basic elements of a medieval landscape were formed between the $7^{\text {th }}$ and $8^{\text {th }}$ centuries. New settlements spread and more evident anthropisation of the landscape began, often combined with changes in rural spatial organisation. This process has been detected in Galicia and Asturias (Ballesteros Arias et al., 2006; Fernández Mier et al., 2014), as well as in the Basque Country (Ruiz-Alonso et al., 2012; Hernández-Beloqui, 2012; Quirós Castillo et al., 2014).

2. The presence of a local ecclesiastical or seigniorial power from the $10^{\text {th }}$ century onwards. This is attested at other sites, such as San Román in Asturias (Fernández Fernández, 2013), but not at others, such as Vigaña, where the influence of a local lord is not detected in this period (Fernández Mier and
Alonso González, 2016). In the Basque Country, one of the most important pieces of evidence for lordly influence is the construction of new agrarian systems based on terraces. Indeed, most of the medieval agrarian terraces in this area were built between the $10^{\text {th }}$ and the $12^{\text {th }}$ centuries (Quirós Castillo et al., 2014).

3. The Zaballa case study reveals the true impact of seigneurial agency on a local scale. From the documentary evidence, it is possible to argue that forms of personal domination are increasingly evident from the $11^{\text {th }}$ century onwards. However, from the Alava Plain there are no examples of entire villages being completely subjugated by a single lord or indeed by several lords, which is in contrast to what occurred in other areas of Alava (Quirós Castillo, 2015). In fact, the impact of seigniorial domination on agrarian practices was not great. However, the Zaballa case study is relevant because it demonstrates that a real and effective lordship dominion occurred in two moments: around the $10^{\text {th }}-11^{\text {th }}$ centuries and during the $13^{\text {th }}$ century, affecting in different ways the production choices, the shape of the landscape and the daily life of the inhabitants. Indeed, it was a lord's decision that prompted the final abandonment of the village (Quirós Castillo, 2017). We may then ask whether this late seigniorial domination attested at Zaballa was an exception or the rule in the social evolution of rural communities in Alava.

\section{ACKNOWLEDGEMENTS}

This work was supported by the project "Peasant agency and social complexity in north-western Iberia in the medieval period" (Spanish Ministry of Economy, Industry and Competitiveness HAR2016-76094-C4-2R), the Research Group in Heritage and Cultural Landscapes (Government of the Basque Country, IT931-16) and the Group of Rural Studies (Unidad Asociada UPV/ EHU-CSIC). Riccardo Santeramo benefits from postgraduate grant from the University of the Basque Country (UPV-EHU). We want to thank Anna Maria Stagno, Amaya Echazarreta-Gallego, Mauro Buonincontri, Emilia Allevato, Gaetano Di Pasquale, Raquel Piqué and Oliver Nelle for their suggestions and inputs.

\section{REFERENCES}

Aizpuru, I., Aseginolaza, C., Uribe-Echebarría, P. Urrutia, Zorrakin, I., 1999. Flora del País Vasco. Gobierno Vasco, Vitoria-Gasteiz.

Aizpuru, I., Catalán P., Garín, F., 2010. Guía de Árboles y Arbustos de Euskal Herria. Gobierno Vasco, Vitoria-Gasteiz.

Alcolea-Gracia, M., Longares-Aladrén, L.A., Cunill-Artigas, R., Royo-Navascués, M., 2016. Aportaciones de la antracología al conocimiento del marco paleoecológico y paleoeconómico del castillo de Juslibol (Zaragoza) en época medieval. Zephyrus 77, 173-189. 
Aseginolaza, C., Gomez, G.D., Lizaur, S.X, Monstserat, M.G., Morante S., G., Salaverria M.M.R., Urribe-Echebarria D.P.M., Alejandre S.J.A., 1985. Catalogo floristico de Alava, Vizcaya y Guipuzcoa. Gobierno Vasco, Vitoria-Gasteiz.

Aseginolaza, C., Gómez-García, D., Montserrat-Martí, G., Morante-Serrano, G., Salaverría-Monfort, M.R., Uribe-Echebarria, P.M., 1989. Vegetación de la Comunidad Autónoma del País Vasco. Gobierno Vasco, Vitoria-Gasteiz.

Asouti, E., Austin, P., 2005. Reconstructing woodland vegetation and its exploitation by past societies, based on the analysis and interpretation of archaeological wood charcoal macro-remains. Environmental Archaeology 10, 1-18.

Aston, M., 1985. Interpreting the landscape. Landscape archaeology in local studies. Routledge, London.

Bagella, S., Caria, M.C., 2011. Vegetation series: a tool for the assessment of grassland ecosystem services in Mediterranean large-scale grazing systems. Fitosociologia 48(2) suppl. 1, 47-54

Ballesteros Arias, P., Criado Boado, F., Andrade Cernadas, J.M., 2006. Formas y fechas de un paisaje agrario de época medieval: A Cidade da Cultura en Santiago de Compostela. Arqueología espacial 26, 193-225.

Barceló, M., 1988. Arqueología medieval. En las afueras del "medievalismo". Crítica, Barcelona.

Barceló, M., Toubert, P. (Eds.), 1998. L'incastellamento. actas de las reuniones de Girona, 26-27 noviembre 1992, y de Roma, 5-7 mayo 1994. CSIC, Escuela Española de Historia y Arqueología en Roma, Roma.

Bazzana, A., 1978. Les villages désertés de l'Espagne orientale: état présent et perspectives d'une recherche archéologique. Archéologie Médiévale 8, 165-223.

Beresford, M., Hurst, J.G., 1971. Deserted Medieval Villages Studies. Lutterworth press, London.

Beug, H.J., 1975. Man as a factor in the vegetational history of the Balkan Peninsula, Problems of Balkans flora and vegetation. Proceedings of the First International Symposium on Balkan Flora and Vegetation. Bulgarian Academy of Sciences, Sofia, $72-77$

Burjachs, F., López-Sáez, J.A., Iriarte-Chiapusso, M.J., 2003. Metodología arqueopalinológica. In: Buxó, R., Piqué, R. (Eds.), La recogida de muestras en arqueobotánica: objetivos y propuestas metodológicas. Museu d'Arqueologia de Catalunya, Barcelona, 11-18.

Buxó, R., Piqué. R., 2008. Arqueobotánica. Los usos de las plantas en la Península Ibérica. Ariel, Barcelona.

Carrión-García, J.S., Sánchez-Gómez, P., 1992. Palynological data in support of the survival of walnut (Juglans regia L.) in the western Mediterranean area during last glacial times. Journal of Biogeography 19, 623-630.

Chabal, L., 1988. Pourquoi et comment prélever les charbons de bois pour la période antique: les méthodes utilisées sur le site de Lattes (Herault). Lattara 1, 187-222.

Chabal, L., 1994. Apports récents de l'anthracologie a la connaissance des paysages passés: performances et limites. Histoire \& Mesure 9 (3-4), 317-338.

Chabal, L., 1997. Forêts et sociétés en Languedoc (Néolithique final, Antiquité tardive): I'anthracologie, méthode et paléoécologie. Editions de la Maison des Sciences de l'Homme, Paris.

Chabal, L., Fabre, L., Terral, J.F., Théry-Parisot, I., 1999. L'anthracologie. In: Ferdiere A. (Ed.), La botanique, 43-104. Errance, Parigi.
Chapelot, J., Fossier, R., 1980. Le village et la maison au Moyen Age. Hachette, Paris.

Charles, M., Crowther, A., Ertug, F., Herbig, C., Jones, G., Kutterer, J., Longford, C., Madella, M., Maier, U., Out, W., Pessin, H., Zurro, D., 2009. Archaeobotanical Online Tutorial <http:// archaeobotany.dept.shef.ac.uk/>.

Corella, J.P., Stefanova, V., Anjoumi, A.E., Rico E., Giralt, S., Moreno, A., Plata-Montero, A., Valero-Garcés, B.L., 2013. A 2500-year multi-proxy reconstruction of climate change and human activities in northern Spain: the lake Arreo record. Palaeogeography, Palaeoclimatology, Palaeoecology 386, 555-568.

Costa-Casais, M., Martínez Cortizas, A., Kaal, J., Caetano Alves, M.I., Criado-Boado, F., 2012. Reconstructing Holocene evolution in the archaeological site of Campo Lameiro (NW Spain): an interdisciplinary approach to geoarchaeology. In: Campar Almeida, A., Bettencourt Ana, M.S., Moura, D., Monteiro-Rodriguez, S., Caetano Alves, M.I. (Eds.), Environmental changes and human interaction along the western Atlantic edge, 51-69. Coimbra.

Court-Picon, M., Buttler, A., Beaulieu, J.L., 2006. Modern pollen/vegetation/land-use relationships in mountain environments: an example from the Champsaur valley (French Alps). Vegetation History and Archaeobotany 15, 151-168.

Davasse, B., 2000. Forêts, charbonniers et paysans dans les Pyrénées de l'est du Moyen Age à nos jours: une approche géographique de l'histoire de l'environnement. Geode, Universitè de Toulouse, Toulouse.

Demoule, J.P., 2012. Rescue Archaeology: A European View. Annual Review of Anthropology 41, 611-626.

Di Pasquale, G., Buonincontri, M.P., Allevato, E., Saracino, A., 2014. Human-derived landscape changes on the northern Etruria coast (western Italy) between Roman times and the late Middle Ages. The Holocene 24(11), 1491 -1502.

Díaz de Durana, J.R., 2012. Historia de un despoblado medieval en tierras alavesas: Zaballa durante los siglos XV y XVI. In: Quirós Castillo, J.A. (Ed.), Arqueología del campesinado medieval. La aldea de Zaballa, 98-135. Universidad del País Vasco, Vitoria-Gasteiz.

Dimbleby, G.W., 1985. The Palynology of archaeological sites. Academic Press, London.

Dupin, A., Girardclos, O., Frucharta, C., Laplaigea, C., Nuningera, L., Dufraissed, A., Gauthierb, E., 2017. Anthracology of charcoal kilns in the forest of Chailluz (France) as a tool to understand Franche-Comte forestry from the mid-15th to the early 20th century AD. Quaternay Internationl 458, 200-213.

Durand, A., Leveau, P., 2004. Farming in Mediterranean France and rural settlement in the late roman and Early Medieval periods: the contribution from archaeology and environmental science in the last twenty years (1980-2000). In: Barceló, M., Sigaut, F. (Ed.), The Making of Feudal Agriculture. Leiden-Boston, 177-253.

Durand, A., 1998. Les paysages médiévaux du Languedoc (Xe-XIle siècles), Toulouse.

Dyer, C., Jones, R., 2010. Deserted Villages Revisited. University of Hertfordshire Press, Herfordshire.

Euba Rementeria, I., 2005. Vegetación y uso del combustible leñoso en la antigüedad del país vasco: análisis antracológico del yacimiento arqueológico romano de Aloria (Amurrio, Araba). Veleia 22, 111-120.

Fernández Fernández, J., 2013. Aproximación a la génesis y evolución del poblamiento medieval en un territorio de media 
montaña (Bajo Valle del Trubia, Concejos de Proaza, Santo Adriano y Oviedo). Excavaciones Arqueológicas en Asturias $7,331-342$

Fernández Mier, M., Alonso González, P., 2016. Medieval north-west Spain: What can agrarian archaeology tell us about living rural landscapes? In: J. Klápště (Ed.), Agrarian technology in the medieval landscape, Ruralia X, Turnhout, Brepols, 291-308.

Fernández Mier, M., Fernández Fernández, J., Alonso González, P., López Sáez, J.A., Pérez Díaz, S., Hernández Beloqui, B., 2014. The investigation of currently inhabited villages of medieval origin: Agrarian archaeology in Asturias (Spain). Quaternary International 346, 41-55.

Figueiral, I., Mosbrugger, V., 2000. A review of charcoal analysis as a tool for assessing Quaternary and Tertiary environments: achievements and limits. Palaeogeography, Palaeoclimatology \& Palaeoecology 164, 397-407.

Francovich, R., Hodges, R., 2003. Villa to Villages. The transformation of the Roman Countryside in Italy, c. 400-1000. London.

Galop, D., 1998. La forêt, l'homme et le troupeau dans les Pyrénées. 6000 ans d'histoire de l'environnement entre Garonne et Méditerranée. Toulouse, Université de Toulouse.

García-Antón, M., Ruiz-Zapata, M.B., Ugarte, F.M., 1989. Análisis geomorfológico y palinológico de la turbera de Saldropo (Barazar, Zeanuri, Bizkaia). Lurralde 12, 25-44.

García Fernández, E., 2012. Viñedo y vino en Álava durante la Edad Media. In: Arízaga Bolumburu, B., Mariño Veiras, D., Díez Herrera, C., Peña Bocos, E., Solórzano Telechea, J.A., Mundos Medievales. Espacios Sociedades y Poder. Homenaje al profesor José Ángel García de Cortázar y Ruiz de Aguirre. Santander, 1351-1364.

Geoeuskadi, 2014. Eusko Jaurlaritza / Gobierno Vasco. GeoEuskadi. 25 novembre 2014. <http://www.geo.euskadi. eus/s69-15375/es>.

Ginés-López, G., 1982. La guía de INCAFO de los árboles y arbustos de la Península Ibérica, Cornell.

Gorrochategui, J., Yarritu, M.J., Martín, I., Zapata, L., Iriarte-Chiapusso, M.J., 1995. Paleometalurgia del hierro en Bizkaia. Las ferrerías de monte altomedievales. In: Tomàs Morera, E. (Ed.), La Farga catalana en el marco de l'arqueologia siderúrgica. Simposi Internacional sobre la Farga Catalana. Govern d'Andorra. Ministeri d'Afers Socials i Cultura, Ripoll, 229-247.

Gorrotxategi, X., Yarritu, M.J., Kandina, M., Sagarduy, M.J., Iriarte Chiapusso, M.J., Zapata, L., 1999. El poblado de montaña calcolítico al aire libre de llso Betaio (Bizkaia). Estructuras de habitación, materiales arqueológicos, estudio palinológico y antracológico. Isturitz, Cuadernos de Prehistoria-Arqueología 10, 3-204.

Grau-Sologestoa, I., 2015. The Zooarchaeology of Medieval Alava in its Iberian context. British Archaeological Reports, Oxford.

Greguss, P., 1955. Identification of Living Gymnosperms on the Basis of Xylotomy. Budapest.

Grimm, E.C., 1987. CONISS: a FORTRAN 77 program for stratigraphically constrained cluster analysis by the method of incremental sum of squares. Computers \& Geosciences 13, 13-35.

Gutiérrez, J.A., Valor, M., 2014. Castles and Fortifications. In: Valor, M., Gutiérrez, A. (Eds.), The Archaeology of Medieval Spain 1100-1500. Equinox, Sheffield, 148-176.
Halstead, P., O'Shea, J. (Eds.), 1989. Bad year economics: cultural responses to risk and uncertainty. Cambridge University Press, New York, 1989.

Hamerow, H., 2002. Early Medieval Settlements. The Archaeology of Rural Communities in North-West Europe 400-900. Oxford University Press, Oxford.

Hamerow, H., 2012. Rural settlements and society in Anglo-Saxon England. Oxford University Press, Oxford.

Hernández-Beloqui, B., 2012. Estudio palinológico de los espacios agrarios de Zaballa. In: Quirós Castillo, J.A. (Ed.), Arqueología del campesinado medieval, 558-576. La aldea de Zaballa. Universidad del País Vasco, Vitoria-Gasteiz.

Hernández-Beloqui, B., 2015. Los paisajes medievales del norte peninsular: registros paleopalinológicos de la Llanada Alavesa y la Cuenca de Treviño. Ph.D. Thesis, Universidad del País Vasco, Vitoria-Gasteiz, Spain.

Hernandez-Beloqui, B., Iriarte-Chiapusso, M.J., 2009. Aplicación de la Palinología a la reconstruccion del paisaje altomedieval. Avance de resultados para el caso de Aistra. In: Quiros-Castillo, J.A. (Ed.), The Archaeology of Early Medieval Villages in Europe, 429-436. Universidad del País Vasco, Vitoria-Gasteiz.

Hernandez-Beloqui, B., Burjachs, F., Iriarte-Chiapusso, M.J., 2013. Antropización en el paisaje vegetal de epoca visigoda en el centro peninsular a través del registro paleopalinologico. In: Quirós Castillo, J.A. (Ed.), El poblamiento rural de época visigoda en Hispania. Arqueología del campesinado en el interior peninsular, 345-356. Universidad del País Vasco, Vitoria-Gasteiz.

Horden, P., Purcell, N., 2000. The Corrupting Sea. A study of Mediterranean History, Cornell.

Iriarte-Chiapusso, M.J., 1992. El entorno vegetal en la bardenas reales (navarra) durante la prehistoria reciente. Cuadernos de Sección. Historia 20, 359-367.

Iriarte-Chiapusso, M.J., 1994. El paisaje vegetal de la Prehistoria reciente, en el Alto Valle del Ebro y sus estribaciones atlánticas. Datos polínicos, PhD thesis, Universidad del País Vasco, Vitoria-Gasteiz, 393 pp.

Iriarte-Chiapusso, M.J. 1997. El paisaje vegetal de la Prehistoria tardía y primera Historia en el País Vasco peninsular. Isturitz. Cuadernos de Sección. Prehistoria y Arqueología 9, 669-677.

Iriarte-Chiapusso, M.J., 2003. El Holoceno reciente en la Sierra de Aralar: primeros registros palinológicos de la Alta Edad Media. Kobie Paleoantropología 27, 151-162.

Iriarte-Chiapusso, M.J., 2009. Vegetation landscape and the anthropization of the environment in the central sector of the Northern Iberian Peninsula: Current status. Quaternary International 200, 66-76.

Iriarte-Chiapusso, M.J., Zapata L., 1996. El paisaje vegetal prehistórico en el País Vasco. Diputación Foral de Alava, Departamento de Cultura y Euskera, Vitoria-Gasteiz.

Iriarte-Chiapusso, M.J., Muñoz Sobrino, C., Gómez Orellana, L. y Ramil-Rego, P., 2006, Dinámica del paisaje en la Reserva de la Biosfera del Urdaibai durante el Holoceno. III Congreso Español de Biogeografía, pp. 113-117. Servicio editorial Universidad del País Vasco.

Iriarte-Chiapusso, M.J., Ocete-Pérez C.A., Hernández-Beloqui B., Ocete-Rubio R., 2016. Vitis vinífera in the Iberian Peninsula: a review. Plan Biosystems. An International Journal Dealing with all aspects of Plan Biology 151(2), 245-257. 
Iriarte-Chiapusso, M.J., Wood, R., Sáenz de Buruaga, A., 2019. Arrillor cave (Basque Country, northern Iberian Penisula). Chronological, palaeo-environmental and cultural notes on a long Mousterian sequence. Quaternary International 508, 107-115.

Jean-Marc, L., Manon, C., 2013. Deux charbonnières gallo-romainesen grandes fosses, à Enversin sur la commune de Joux (Rhône). In: Armelle, D. (Ed.), Arbres \& dynamiques, 129-153.

Klápště, J. (Ed.), 1995-2016. Conference Ruralia, 1-5. Památry Archjeologiké Supplementum, Prague, 6-10. Brepols, Turhnout.

Klápště, J, Jaubert, A.N., 2007. Rural Settlement. In: Graham-Campbell, J., Valor, M., The Archaeology of Medieval Europe. Vol. 1. Eighth to Twelfth Centuries AD. Aarhus University Press, Aarhus, 76-110.

Loidi, J., Biurrun, I., Campos, J.A., García-Mijangos, I., Herrera, M., 2011. La vegetación de la Comunidad Autónoma del País Vasco. Gobierno Vasco, Leioa.

López-Merino, L., Peña-Chocarro, L., Ruiz-Alonso, M., LópezSáez, J.A., Sánchez-Palencia, F.J., 2010. Beyond nature: The management of a productive cultural landscape in Las Médulas area (El Bierzo, Leoón, Spain) during pre-Roman and Roman times. Plant Biosystems144(4), 909-923.

Loveluck, C., 2013. Northwest Europe in the Early Middle Ages, c. AD 600-1150: A Comparative Archaeology. Cambridge University Press, Cambridge.

Ludemann, T., 2010. Past fuel wood exploitation and natural forest vegetation in the Black forest, the Vosges and neighbouring regions in western Central Europe. Palaeogeography, Palaeoclimatology, Palaeoecology 291, 154-165.

Mansilla, R., 2012. Los metales del yacimiento de Zaballa. In: Quirós Castillo, J.A. (Ed.), Arqueología del campesinado medieval: la aldea de Zaballa, 300-334. Documentos de arqueología medieval 3. Bilbao.

Mazier, F., Galop, D., Brun, C., Buttler, A., 2006. Modern pollen assemblages from grazed vegetation in the western Pyrenees, France: a numerical tool for more precise reconstruction of past cultural landscapes. The Holocene 16, 91-103.

Meaza, G., 1994. Suelos, vegetación y fauna. In: Geografía de Euskal Herria, tomo IV. Editorial Ostoa, San Sebastián.

Meaza G., Zapata L., 1998. Procesos de antropización y cambios en el paisaje vegetal del País Vasco atlántico en la prehistoria reciente y su incidencia en la expansión de hayedos y encinares. Munibe Ciencias Naturales 50, 21-36.

Mercuri, A.M., Allevato, E., Arobba, D., Bandini Mazzanti, M., Bosi, G., Caramiello, R., Castigliani, E., Carra, M.L., Celant, A., Constatini, L., Di Pasquale, G., Fiorentino G., Florenzano A., Guido, M., Marchesini, M., Mariotti Lippi, M., Marvelli, S., Miola, A., Montanari, C., Nisbet, R., Peña-Chocarro, L., Perego, R., Ravazzi, C., Rottoli, M., Sadori, L., Ucchesu, M., Rinaldi, R., 2015. Pollen and macrorremains from Holocene archaeological sites: A dataset for the understanding of the bio-cultural diversity on the Italian landscape. Review of Paleobotany of Palynology 218, 250-266

Michel, M., Gil, L., 2013. La transformación histórica del paisaje forestal en la Comunidad Autónoma de Euskadi. Gobierno Vasco, Vitoria-Gasteiz.

Moreno, D., 1990. Dal Documento al Terreno. Storia e Archeologia dei Sistemi Agro-Silvo-Pastorali. II Mulino, Bologna.
Narbarte Hernández, J., Rodríguez Lejarza, A., Santeramo, R., Quirós-Castillo, J.A., Iriarte Avilés, A., 2018. Evidencias de ocupación antigua en núcleos rurales actualmente habitados: el proyecto arqueológico de Aizarna (Gipuzkoa). Munibe Antropologia-Arkeologia 69, 239-256.

Narbarte-Hernández, J., Iriarte, E., Rad, C., Carrancho-Alonso, Á., González-Sampériz, P., Peña- Chocarro, L., Quirós-Castillo, J.A., 2019. On the origin of rural landscapes: Looking for physico- chemical fingerprints of historical agricultural practice in the Atlantic Basque Country (N Spain). Science of The Total Environment 681, 66-81.

Nelle, O., Dreibrodt, S., Dannath, Y., 2010. Combining pollen and charcoal: evaluating Holocene vegetation composition and dynamics. Journal of Archaeological Science 37, 21262135.

Nicosia, C., Polo-Díaz, A., 2012. Soil micromorphological study of the human impact on the landscape at Zaballa, Iruña de Oca. In: Quirós Castillo, J.A. (Ed.), Arqueología del campesinado medieval: la aldea de Zaballa, 536-549. Universidad del País Vasco.

Ntinou, M., Badal, E., Carrión, Y., Menéndez-Fueyo, L.J., Ferrer-Carrión R., Pina-Mira J., 2013. Wood use in a medieval village: the contribution of wood charcoal analysis to the history of land use during the 13th and 14th centuries A.D. at Pobla d'Ifach (Calp, Alicante, Spain). Vegetation, History and Archaeobotany 22, 115-128.

Orejas, A. and Ruiz del Árbol, M., 2013. Arqueología del paisaje: procesos sociales y territorios. In: Quirós Castillo, J.A., (Ed.), La materialidad de la Historia. La arqueología en los inicios del siglo XXI, 201-240. Akal, Barcelona.

Palet, J.M., 2002. Estudi territorial del Pla de Barcelona: evolució histórica i estructuració del territorio en época romana, segles II/I aC-IX/X d C. Universitat de Barcelona, Barcelona.

Paradis-Grenouillet, S., Allée, P., Servera Vives, G., Alain Ploquin, 2015. Sustainable management of metallurgical forest on Mont Lozère (France) during the Early Middle Ages. Environmental Archaeology 20(2), 168-183.

Peña-Chocarro, L., Zapata, L., 1996. Los recursos vegetales en el mundo romano: estudio de los macrorrestos botánicos del yacimiento calle Santiago de Irún (Guipúzcoa). Archivo Español de Arqueología 69 (173-174), 119-134

Peña-Chocarro, L., Zapata, L., Iriarte-Chiapusso, M.J., Morales, M.G., Straus, L.G., 2005. The oldest agriculture in northern Atlantic Spain: new evidence from El Mirón Cave (Ramales de la Victoria, Cantabria). Journal of Archaeological Science 32(4), 579-587

Pérez Díaz, S., 2012. El paisaje vegetal durante la Prehistoria reciente en la vertiente mediterránea de Euskal Herria. Ph.D. Thesis, Universidad del País Vasco, Vitoria-Gasteiz.

Pérez Díaz, S., López-Sáez J. A., Zapata, L., López-Merino, L., Ruiz-Alonso, M., Azkarate-Garai-Olaun, A., Solaun-Bustinza, J.L., 2009. Dos contextos, una misma historia: paleopaisaje y paleoeconomía de Vitoria-Gasteiz (Álava) durante la Edad Media. Cuadernos de la Sociedad Española de Ciencias Forestales 30, 115-120.

Pérez Díaz, S. and López Sáez, J.A., 2012. Paisajes medievales: paleoambiente y antropización en Treviño en los últimos 1800 años, in: González de Viñaspre Gonzalo, R., Garay Osma, R. (Eds.), Viaje a Íbita. Estudios históricos del Condado de Treviño. Ayuntamiento de Condado de Treviño, Condado de Treviño, 377-390. 
Pérez Díaz, S., López Sáez, J.A., 2014. 23. Prados de Randulanda peat bog (Basque Country, Northern Iberian Peninsula, Spain). Grana 53, 252-254.

Pérez-Díaz, S., Ruiz-Alonso, M., López-Sáez, J.A., Solaun-Bustinza, J.L., Azkarate, A., Zapata, L., 2015. A palaeoenvironmental and palaeoeconomic approach to the Early Middle Age record from the village of Gasteiz (Basque Country, Northern Iberian Peninsula). Veget Hist Archaeobot 24, 683-697.

Périn, P., 2004. The Origin of th Village in Early Medieval Gaul. In: Christie N. (Ed.), Landscapes of change: Rural Evolutions in Late Antiquity and the Early Middle Ages, 255-278. Aldershot.

Peytremann, E., 2003. Archéologie de l'habitat rural dans le nord de la France du IVe au XIle siècle. Association Française d'Archéologie Mérovigienne, Saint-Germain-en-Laye.

Piqué, R., 1999. Producción y uso del combustible vegetal: una evaluación arqueológica. Treballs d’Etnoarqueologia 3. Universidad Autónoma de Barcelona. Consejo Superior de Investigaciones Científicas. Madrid.

Pott, R., 1985. Vegetationsgeschichtliche und pflanzensoziologische Untersuchungen zur Niederwaldwirtschaft in Westfalen. Abh. Westfäl. Museum f. Naturkunde 47(4).

Quirós Castillo, J.A., 2007. Las aldeas de los historiadores y de los arqueólogos en la Alta Edad Media del norte peninsular. Territorio, Sociedad y Poder 2, 65-86.

Quirós Castillo, J.A. (Ed.), 2009. The Archaeology of Early Medieval villages in Europe. Bilbao, University of the Basque Country.

Quirós Castillo, J.A., 2012. Arqueología del campesinado medieval: la aldea de Zaballa. Universidad del País Vasco.

Quirós Castillo, J.A., 2013. Medieval Deserted Villages in Alava (Spain): The Zaballa Project, Medieval Settlement Research 28, 1-8.

Quirós Castillo J.A., 2015. The Other Spain. The formation of seigneurial society in Alava. In: S. Gelichi and R. Hodges (Eds.), New Directions in Early Medieval European Archaeology: Spain and Italy compared. Essays for Riccardo Francovich, Brepols, 111-133.

Quirós Castillo, J.A., 2016. Dalla periferia: Archeometallurgia del ferro nella Spagna Nord-Occidentale nell'alto e pieno medioevo. In: Molinari, A., Santangeli Valenzani, R., Spera, L. (Eds)., L'archeologia della produzione a Roma (secoli V-XV), 597-612. Roma.

Quirós Castillo, J.A., 2017. Identidades locales y despoblamiento en la Baja Edad Media. Microhistorias y tendencias a través de la arqueología de los despoblados de Álava (País Vasco), Reti Medievali 18(2), 89-121.

Quirós Castillo, J.A., Nicosia, C., Polo-Díaz, A., Ruiz del Árbol, M., 2014. Agrarian archaeology in northern Iberia: Geoarchaeology and early medieval land use. Quaternary International 346, 56-68.

Rackham, O., 1982. Boschi e storia dei sistemi sivlopastorali in Inghilterra. Quaderni Storici 49(XVII), 16-49.

Rendu, C., 2003. La montagne d'Enveig, une estive pyrénéenne dans la longue durée. Trabucaire.

Riera Mora, S., 2008. Los paisajes vegetales de la España mediterránea a lo largo de la Historia. In: Garrabou, F., Naredo, J.M., El paisaje en perspectiva histórica: formación y transformación del paisaje en el mundo mediterráneo, 21-45. Madrid.

Rippon, S.J., 2008. Beyond the medieval village. The diversification of Landscape Character in Southern Britain, Oxford.
Riu Riu, M., 1999. Aportación de la arqueología medieval a la historia de España. In: La Historia Medieval en España. Un balance historiográfico (1968-1988). 15th Semana de Estudios Medievales, Estella, Pamplona, 403-430. Gobierno de Navarra.

Robinson, M., Hubbard, R.N.L.B., 1977. The Transport of PoIlen in the Bracts of Hulled Cereals. Journal of Archaeological Science 4, 197-199.

Roig Buxó, J., 2011. Formas de poblamiento rural y producciones cerámicas en torno al 711: documentación arqueológica del área catalana. Zona Arqueológica 11, 121-144.

Ruiz de Loizaga, S., 1988. La viña en el occidente de Álava en la Alta Edad Media: 850-1150, cuenca Omecillo-Ebro. Aldecoa, Burgos.

Ruiz del Árbol, M., 2012. Análisis químicos. In: Quirós Castillo, J.A., (Ed.), Arqueología del campesinado medieval: la aldea de Zaballa. Documentos de arqueología medieval 3, 549-558.

Ruiz-Alonso, M., 2003. Madera carbonizada en los fondos de cabaña de Arrubi y Esnaurreta (Sierra de Aralar, Gipuzkoa): vegetación y recursos forestales en la Edad Media. Kobie Paleoantropología 27, 131-150.

Ruiz-Alonso, M., Zapata, L., 2009. Macrorrestos vegetales de Santa María la Real de Zarautz (País Vasco): cultivos y bosques en época romana y altomedieval. In: Ibáñez Etxeberria, A. (Ed.), Santa María la Real de Zarautz (País Vasco). Continuidad y discontinuidad en la ocupación de la costa vasca entre los siglos V a. C. y XIV d. C., 132-150. Sociedad de Ciencias Aranzadi, Donostia-San Sebastián.

Ruiz-Alonso, M., Martínez Torrecilla, J.M., Zapata, L., 2009. Macrorrestos vegetales del yacimiento arqueológico de Las Eras de San Martín (Alfaro, La Rioja). Kobie Paleoantropología 28, 153-170.

Ruiz-Alonso, M., Pérez Díaz, S., López Sáez, J.A., Zapata, L., 2011. Carbón y polen. Un ejemplo de comparación de dos registros arqueobotánicos en Álava durante la Edad del Bronce: Peña Parda. Kobie Paleoantropología 30, 63-72.

Ruiz-Alonso, M., Azkarate, A., Solaun-Bustinza, J.L., Zapata, L., 2012. Exploitation of fuelwood in Gasteiz (Basque Country, Northern Iberia) during the Middle Ages (700-1200 AD). Saguntum Extra 13, 227-236.

Sánchez-Goñi, M.F., 1988. A propos de la présence du pollen de Castanea et Juglans dans les sédiments archéologiques würmiens anciens du Pays Basque espagnol. Travaux de la Section scientifique et technique, Institut Français de Pondichéry XXV, 73-82.

Santeramo, R., 2019. El estudio antracológico de la aldea medieval de Zornoztegi. In: Quirós-Castillo J.A. (Ed.), Documentos de arqueología medieval 13, 452-480.Universidad del País Vasco, Bilbao.

Schweingruber, F.H., 1990. Anatomy of European Woods. Berne.

Shackleton, C.M., Prins, F., 1992. Charcoal analysis and the "Principle of least Effort" e a Conceptual Model. Journal of Archaeological Science 19, 631-637.

Schoch, W., Heller, I., Schweingruber, F.H., Kienast, F., 2004. Wood anatomy of central European Species. Disponible en: www.woodanatomy.ch

Sirignano, C., Grau-Sologestoa, I., Ricci, P., García-Collado, M.I., Altieri, S., Quirós Castillo, J.A., Lubritto, C., 2014. Animal husbandry during Early and High Middle Ages in the Basque Country (Spain). Quaternary International 346, 138-148. 
Smart, T.L., Hoffman, E.S., 1988. Environmental Interpretation of archaeological charcoal. In: Hastorf, C.A., Popper, V.S. (Eds.), Current Paleoethnobotany. Analytical Methods and Cultural Interpretations of Archaeological Plant Remains167-205. The University of Chicago Press, Chicago and London.

Sopelana, I., 2012. Estudio arqueobotánico del yacimiento de Zaballa (Iruña de Oca, Alava). In: Quirós Castillo, J.A. (Ed.), Arqueología del campesinado medieval: la Aldea de Zaballa. Documentos de arqueología medieval 3, 452-480. Universidad del País Vasco, Bilbao.

Sopelana, I., Zapata L., 2009. Primeros resultados de los estudios carpológicos del despoblado de Zornoztegi (Savatierra-Agurain, Álava). In: Quirós-Castillo, J.A. (Ed.), The archaeology of early medieval villages in Europe. Documentos de arqueología e historia 1, 437-445. Universidad del País Vasco, Bilbao.

Teira-Brión, A., 2013. Dentro y fuera del bosque. La gestión de Prunus avium/cerasus en época romana y medieval en el NW Ibérico. Revista Arkeogazte 3, 99-115.

Théry-Parisot, I., Chabal, L., Chrzavzez, J., 2010. Anthracology and taphonomy, from wood gathering to charcoal analysis. A review of the taphonomic processes modifying charcoal assemblages in archaeological contexts. Palaeogeography, Palaeoclimatology, Palaeoecology 291, 142-153.

Uzquiano, P., 1992. Recherches anthracologiques dans le secteur pyrénéo-cantabrique (Pays Basque, Cantabria et Asturias). Environnements et relations homme-milieu au Pléistocéne supérieur et début de l'Holocéne. Ph.D. thesis, Université des sciences et techniques, Montpellier.

Valenti, M., 2004. L'insediamento altomedievale nelle campagne toscane. Paesaggi, popolamento e villaggi tra VI e X secolo. All'Insegna del Giglio, Firenze.

Valenti, M., 2014. Archeologia delle campagne altomedievali: diacronie e forme dell'Insediamento. In: Gelichi, S. (Ed)., Quarant'anni di Archeologia Medievale in Italia. La rivista, i temi, la teoria e i metodi,123-142. Firenze.

Vernet, J.L., 1973. Etude sur l'histoire de la végétation du SudEst de la France au Quaternaire d'après les charbons de bois principalement, Paléobiologie continentale 4(1), 1-90.

Vernet, J.L., 1991. L'anthracologie, donnes actuelles, problemes. El análisis de los macrorrestos vegetales en la interpretación arqueológica. Madrid.

Vernet, J.L., Ogereau, P., Figueiral, I., Machado-Yanes, C., Uzquiano, P., 2001. Guide d'identification des charbons de bois préhistoriques du sud-ouest de l'Europe, Paris.

Vigil-Escalera, A., 2005. Granjas y aldeas altomedievales al Norte de Toledo (450-800 D. C.). Archivo Español de Arqueología 80, 239-284.

Vigil-Escalera, A., Moreno-García, M., Peña-Chocarro, L., Morales-Muñiz, A., Llorente-Rodríguez, L., Sabato, D., Ucchesu, M., 2014. Productive strategies and consumption patterns in the Early Medieval village of Gózquez (Madrid, Spain). Quaternary International 346, 7-19.

Vignote-Peña, S., Picos-Martín, J., Zamora-Paniagua, R., 2000. Características de las principales maderas utilizadas en Bizkaia: Tecnología y aplicaciones. Diputación Foral de Bizkaia, Bilbao.

Zadora-Rio, E., 1995. Le village des historiens et le village des archéologues. In: Mornet, E. (Ed.), Campagnes médiévales: L'Homme et son espace, 143-153. Études offertes à Robert Fossier, Paris.
Zapata, L., 1997. El uso del combustible en la ferrería medieval de Oiola IV: implicaciones ecológicas y etnobotánicas. Kobie Paleoantropología 24, 107-115.

Zapata, L., 1999. La explotación de los recursos vegetales y el origen de la agricultura en el País Vasco: Análisis arqueobotánico de macrorrestos vegetales. PhD thesis, Universidad del País Vasco

Zapata, L. and Peña-Chocarro, L., 1998. La historia del bosque y su explotación en el pasado: evidencia arqueológica y etnográfica. Zainak 17, 89-99.

Zapata, L. and Ruiz Alonso, M., 2013. Agricultura altomedieval y usos forestales en Gasteiz. Datos carpológicos y antracológicos. In: Azkarate Garai-Olaun, A., Solaun Bustinza, J.L. (Eds.), Arqueología e Historia de una ciudad. Los orígenes de Vitoria-Gasteiz (I), 254-278. Universidad del País Vasco. 